Prepared in cooperation with the Sac and Fox Tribe of the Mississippi in lowa

\title{
Nutrient Concentrations, Loads, and Yields in the Middle lowa River Basin, lowa
}

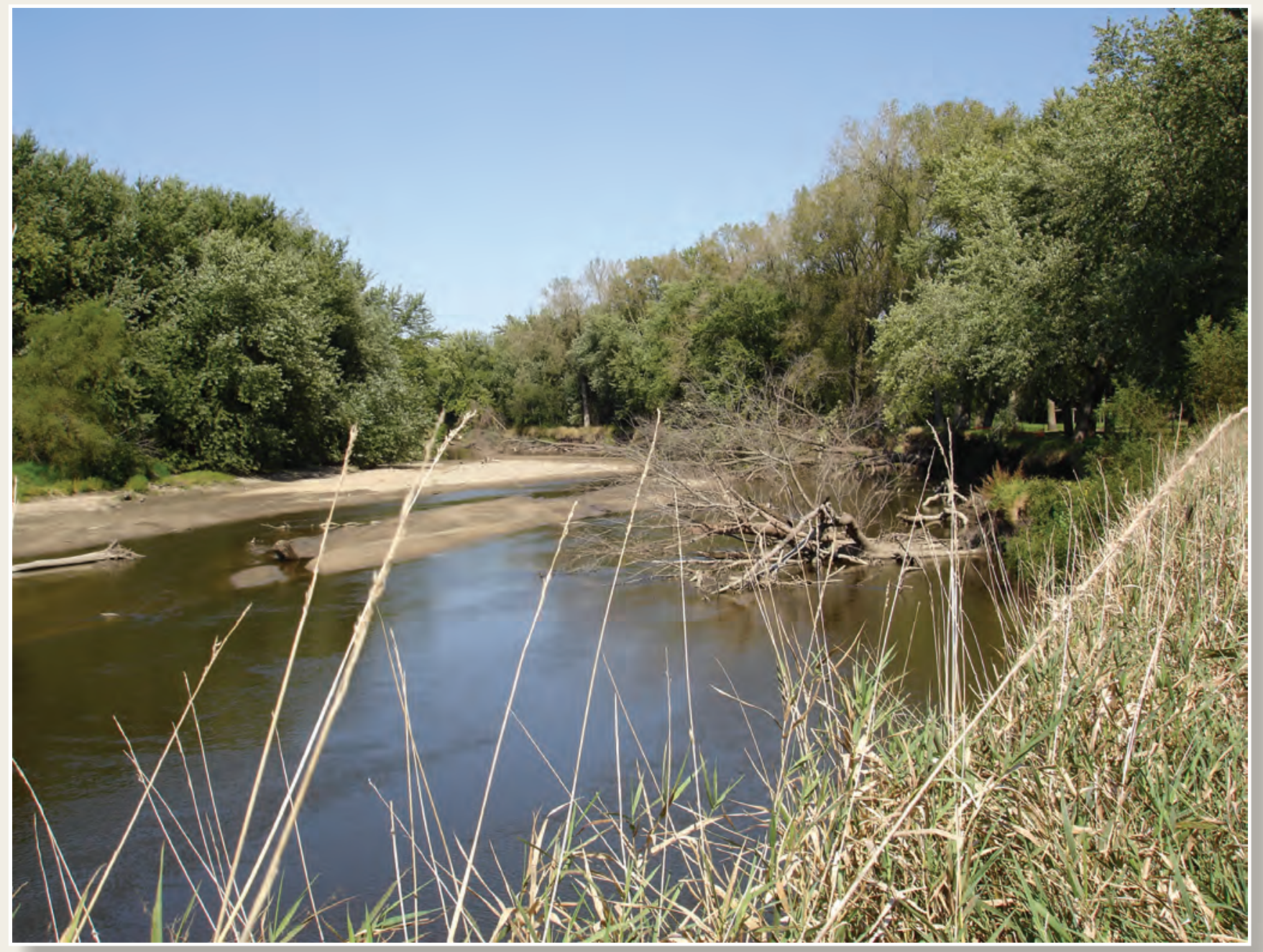

Scientific Investigations Report 2020-5148 
Cover: Photograph showing the lowa River near the Meskwaki Settlement in Tama County, lowa, by Gregory R. Littin, U.S. Geological Survey, September 20, 2005. 


\title{
Nutrient Concentrations, Loads, and Yields in the Middle lowa River Basin, lowa
}

\author{
By Jessica D. Garrett and Stephen J. Kalkhoff
}

Prepared in cooperation with the Sac and Fox Tribe of the Mississippi in lowa

Scientific Investigations Report 2020-5148 


\section{U.S. Geological Survey, Reston, Virginia: 2021}

For more information on the USGS - the Federal source for science about the Earth, its natural and living resources, natural hazards, and the environment—visit https://www.usgs.gov or call 1-888-ASK-USGS.

For an overview of USGS information products, including maps, imagery, and publications, visit https://store.usgs.gov/.

Any use of trade, firm, or product names is for descriptive purposes only and does not imply endorsement by the U.S. Government.

Although this information product, for the most part, is in the public domain, it also may contain copyrighted materials as noted in the text. Permission to reproduce copyrighted items must be secured from the copyright owner.

Suggested citation:

Garrett, J.D., and Kalkhoff, S.J., 2021, Nutrient concentrations, loads, and yields in the Middle lowa River Basin, lowa: U.S. Geological Survey Scientific Investigations Report 2020-5148, 22 p., https://doi.org/10.3133/sir20205148.

Associated data for this publication:

U.S. Geological Survey, 2019, USGS water data for the Nation: U.S. Geological Survey National Water Information System database, https://doi.org/10.5066/F7P55KJN.

ISSN 2328-0328 (online) 


\section{Acknowledgments}

The authors wish to thank the Sac and Fox Tribe of the Mississippi in lowa, U.S. Army Corps of Engineers, and lowa Department of Transportation for funding the operation and maintenance of the gages and lowa Department of Natural Resources and U.S. Environmental Protection Agency for sample data used for this study. Additionally, Lance R. Gruhn and Erik A. Smith contributed valuable review comments to the betterment of this report. 



\section{Contents}

Acknowledgments ……...................................................................................................................

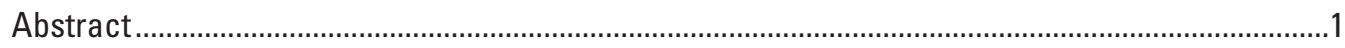

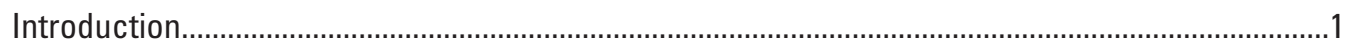

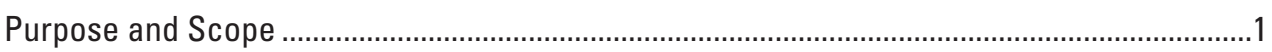

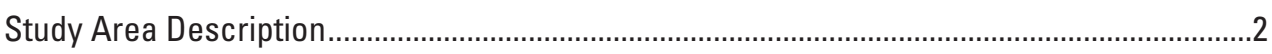

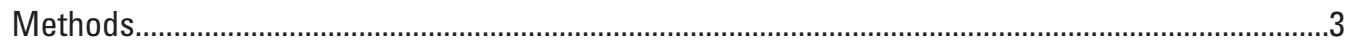

Aggregation of Streamflow and Nutrient Concentration Data .................................................

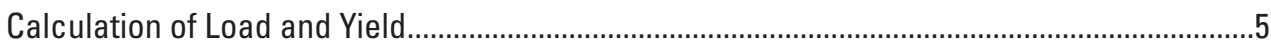

lowa River Nutrient Concentrations, Loads, and Yields.................................................................

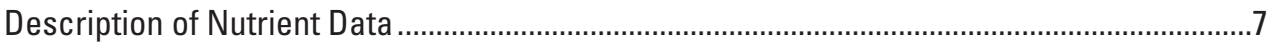

Annual and Seasonal Nutrient Loads...................................................................................

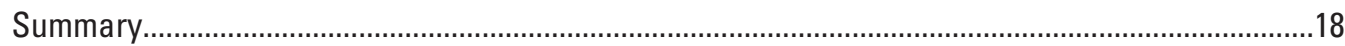

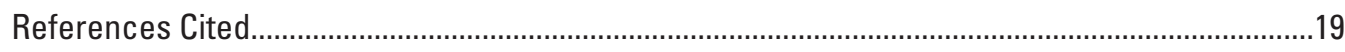

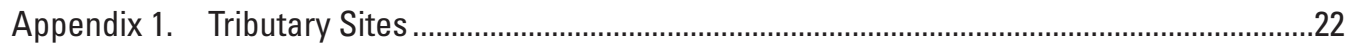

\section{Figures}

1. Map showing location of Middle lowa River drainage basin and selected water-quality sampling sites and streamgages along the lowa River ...............................2

2. Graph showing long-term annual average streamflow in the lowa River at Marshalltown, lowa, in relation to annual precipitation in the Upper lowa River Basin

3. Graphs showing nutrient concentrations in samples from the lowa River and tributary sites in the Middle lowa River Basin, upstream from Coralville Reservoir, lowa

4. Graphs showing relation between streamflow and nutrient concentrations in the lowa River with loess smoothed lines, 1980-2019

5. Graphs showing nutrient loads in the Middle lowa River Basin, upstream from Coralville Reservoir, lowa, 1980-2018.

6. Graph showing annual nitrate loads in the lowa River, 2011-18, with running average of the preceding 5 years relative to average loads from historical comparison periods $1980-96$ and $2006-10$ and 45 -percent reduction of the historical loads

7. Graphs showing nutrient yields in relation to annual runoff in the Middle lowa River Basin with linear trend lines for 1980-96, 2006-10, and 2011-18

\section{Tables}

1. Description of lowa River nutrient sampling sites

2. Summary of nutrient concentrations in stream samples from the Middle lowa River Basin upstream from Coralville Reservoir, lowa, 1980-2018.

3. Average annual and seasonal nutrient loads and yields for the Middle lowa

River Basin upstream from Coralville Reservoir, 1980-2018. 


\section{Conversion Factors}

U.S. customary units to International System of Units

\begin{tabular}{lcl}
\hline & Multiply & \multicolumn{1}{c}{ By obtain } \\
\hline inch (in.) & Length & \\
inch (in.) & 2.54 & centimeter $(\mathrm{cm})$ \\
foot (ft) & 25.4 & millimeter $(\mathrm{mm})$ \\
mile (mi) & 0.3048 & meter $(\mathrm{m})$ \\
\hline & 1.609 & kilometer $(\mathrm{km})$ \\
\hline acre & Area & \\
acre & 4,047 & square meter $\left(\mathrm{m}^{2}\right)$ \\
acre & 0.4047 & hectare $($ ha $)$ \\
acre & 0.4047 & square hectometer $\left(\mathrm{hm}^{2}\right)$ \\
square mile $\left(\mathrm{mi}^{2}\right)$ & 0.004047 & square kilometer $\left(\mathrm{km}^{2}\right)$ \\
square mile $\left(\mathrm{mi}^{2}\right)$ & 259.0 & hectare $($ ha $)$ \\
\hline & 2.590 & square kilometer $\left(\mathrm{km}^{2}\right)$ \\
\hline cubic foot per second $(\mathrm{ft} 3 / \mathrm{s})$ & Flow rate & \\
\hline & 0.02832 & cubic meter per second $\left(\mathrm{m}^{3} / \mathrm{s}\right)$ \\
\hline ton, short $(2,000 \mathrm{lb})$ & Mass & \\
\hline pound per acre $(\mathrm{lb} / \mathrm{acre})$ & 0.9072 & metric ton $(\mathrm{t})$ \\
\hline
\end{tabular}

\section{Datum}

Horizontal coordinate information is referenced to the Universal Transverse Mercator (UTM) coordinate system, zone 15 North.

\section{Supplemental Information}

Concentrations of chemical constituents in water are given in milligrams per liter (mg/L). 


\section{Abbreviations}

$\begin{array}{ll}\text { EPA } & \text { U.S. Environmental Protection Agency } \\ \text { HUC } & \text { hydrologic unit code } \\ \text { IADNR } & \text { lowa Department of Natural Resources } \\ \text { LOADEST } & \text { LOAD ESTimator } \\ \text { MDNR } & \text { Meskwaki Department of Natural Resources } \\ \text { NRS } & \text { nutrient reduction strategy } \\ \text { USGS } & \text { U.S. Geological Survey } \\ \text { UTM } & \text { Universal Transverse Mercator } \\ \text { WRTDS } & \text { weighted regression on time, discharge, and season }\end{array}$





\title{
Nutrient Concentrations, Loads, and Yields in the Middle lowa River Basin, lowa
}

\author{
By Jessica D. Garrett and Stephen J. Kalkhoff
}

\section{Abstract}

Concentrations, loads, and yields of nitrate plus nitrite, total nitrogen, and total phosphorus were assessed in the Iowa River upstream from the Coralville Reservoir in east-central Iowa. The results of this study describe baseline nutrient transport during two historical reference periods, 1980-96 and 2006-10, that can be used to evaluate the progress of the implementation of reduction strategies in the Middle Iowa River Basin. Where available, nutrient data during the more recent period 2011-18 are also described. Data included nutrient concentrations and streamflow from multiple Federal, State, and Tribal agencies, and loads were computed using multiple techniques to provide valuable insights, which would otherwise not be possible.

Despite an upward trend for mean annual and base streamflow (the trend in high streamflow was not significant), average nutrient loads and yields in the Iowa River were smaller in the recent period (2011-18) than in either historical reference period. Notably smaller loads during the 2012 drought, however, caused pronounced skewed average loads for 2011-18. Comparisons among periods were difficult to make because of a short period of data upstream from Marshalltown, Iowa, at the upstream boundary of the study area and a lack of recent data near Marengo, Iowa, at the downstream boundary of the study area. Though spring and summer loads were a disproportionate part of annual loads, up to 90 percent, seasonal load comparisons to determine load reduction were more sensitive to one or the other historical period than was assessment of annual loads. Runoff-transport relations may provide an additional tool to assess load reduction.

\section{Introduction}

The State of Iowa nutrient reduction strategy (NRS) calls for a 45-percent reduction in both total phosphorus and total nitrogen annual loads statewide by 2035 but does not establish guidelines for numeric nutrient criteria for concentrations (Iowa Department of Agriculture and Land Stewardship and others, 2017). The Iowa NRS assesses the reduction relative to two historical comparison periods-1980-96 [based on the Gulf of Mexico Hypoxia Action Plan (U.S. Environmental Protection Agency, 2008)] and 2006-10 (owing to greater data availability). Local groups and agencies have used methodology similar to the statewide plan to apportion watershed load reduction goals (Iowa Department of Agriculture and Land Stewardship and others, 2017). The Sac and Fox Tribe of the Mississippi in Iowa (Meskwaki Tribe), is federally recognized for the purposes of administering nutrient criteria, with a similar need to apportion statewide load reduction goals.

Stream sampling programs that balance multiple objectives are often not ideally suited for computing annual loads. For example, open-water seasonal sampling of the Iowa River on the Meskwaki Settlement is protective of human health. Both nutrient and bacteria sampling coincide with the time when there is the greatest risk for drinking source water contamination and for elevated bacteria levels. Determining a seasonal, local concentration standard based on statewide load reduction goals presents several challenges, including (1) the overall load-reduction goal is statewide, allowing for locally greater or less reduction where reduction practices may have greater or lesser effectiveness or implementation; (2) loads are intrinsically linked with streamflow; and (3) data from stream monitoring programs are not always ideal for computing annual loads. Results from the study are needed for development of stream nutrient criteria, a vital tool in longterm monitoring, managing, and protecting the Iowa River for the purposes of nutrient load reduction, protection of human health, and honoring the cultural importance of the river. This study was conducted by the U.S. Geological Survey (USGS) in cooperation with the Sac and Fox Tribe of the Mississippi in Iowa, to compare nutrient and streamflow data in the Middle Iowa River Basin among three time periods.

\section{Purpose and Scope}

The purpose of this report is to describe annual and seasonal nitrate plus nitrite (nitrate), total nitrogen, and total phosphorus concentrations and loads in the Iowa River upstream from the Coralville Reservoir during 1980-96, 2006-10, and 2011-18. Concentrations and loads are presented for four locations on the Iowa River-upstream and downstream from Marshalltown, Iowa, near Tama, Iowa, and 
near Marengo, Iowa (fig. 1). Concentrations (not loads) from tributary sites in the basin also are summarized. Sample data associated with a fifth location, Iowa River near Belle Plaine, Iowa, were too sparse for summary and trend analysis. Data used for this analysis were compiled from stream and river monitoring data collected by the Iowa Department of Natural Resources (IADNR), Meskwaki Department of Natural Resources (MDNR), U.S. Environmental Protection Agency (EPA), and USGS.

\section{Study Area Description}

The Middle Iowa River Basin (hydrologic unit code, HUC 07080208) area is composed of 1,656 square miles ( $\left.\mathrm{mi}^{2}\right)$ extending south-east from northern Marshall County in central Iowa to the outlet of the Coralville Reservoir in northern Johnson County (U.S. Department of Agriculture, 2011); however, this report focuses on the approximately $1,504 \mathrm{mi}^{2}$ of the basin upstream from the Coralville Reservoir (fig. 1). Sampled tributaries to the Iowa River above Coralville Reservoir are described in appendix 1. The Upper Iowa River drainage basin upstream from the upper bound of the study area upstream from Marshalltown encompasses another 1,456 $\mathrm{mi}^{2}$.

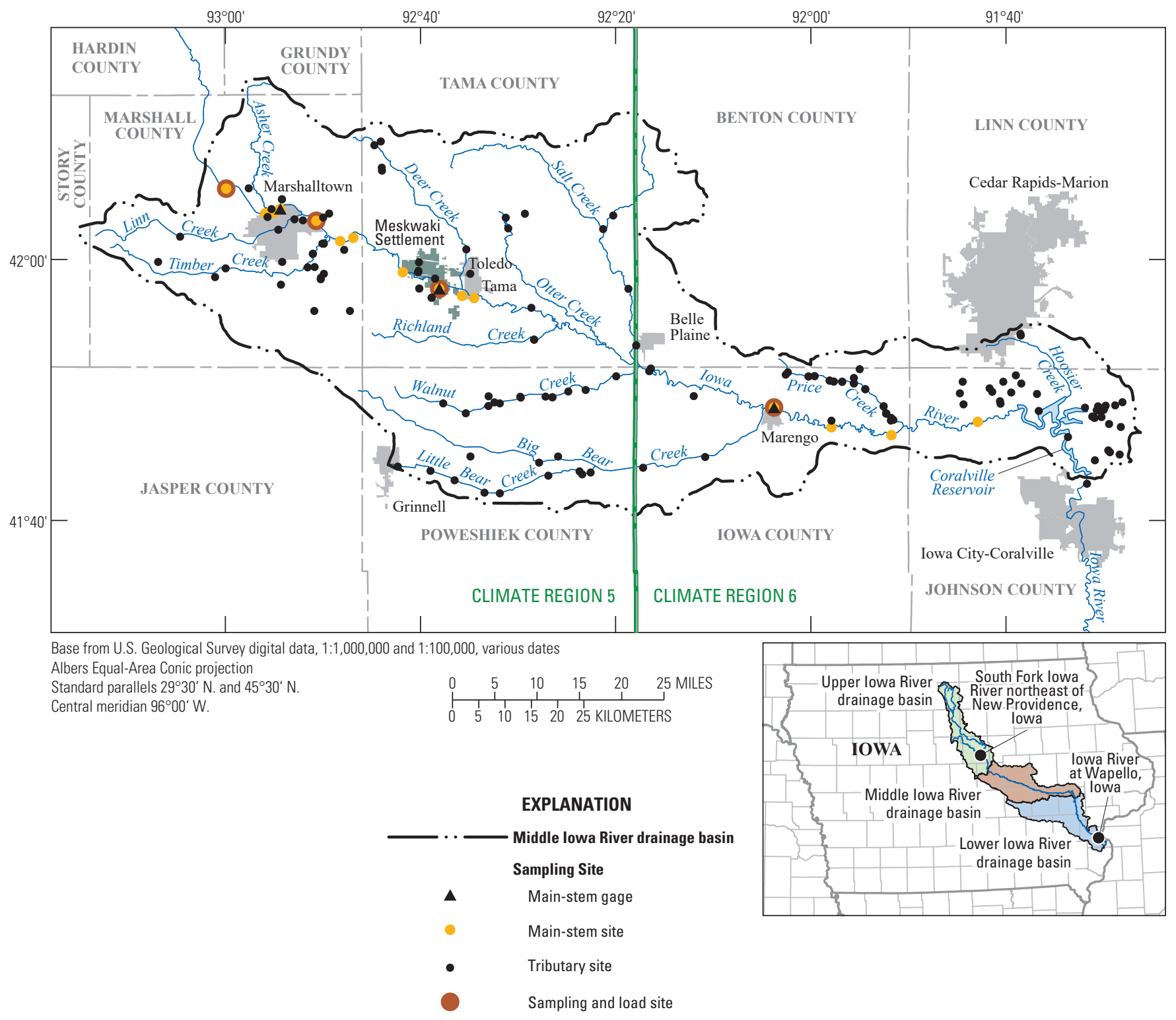

Figure 1. Location of Middle lowa River drainage basin and selected water-quality sampling sites and streamgages along the lowa River. 
The land surface of the Middle Iowa River Basin ranges from nearly flat to gently rolling glacial till plains with thin loess deposits and a well-established drainage network (Prior, 1991; U.S. Environmental Protection Agency, 2018). Approximately 80 percent of the Middle Iowa River Basin is used for agriculture, mostly for cropland with some pasture. Another 9 percent of the basin is natural woodlands, 9 percent is urban areas, and the remaining 2 percent is water or wetlands, though much of these wet areas include Coralville Reservoir and surrounding wetlands (U.S. Department of Agriculture, 2011).

The basin is primarily rural with population densities ranging from approximately 24 to 70 people per square mile for Iowa, Marshall, Poweshiek, and Tama Counties, which represent most of the basin. Towns and cities above Coralville Reservoir with populations greater than 2,000 include Marshalltown, Grinnell, Tama, Toledo, Belle Plaine, and Marengo (U.S. Census Bureau, 2010) (fig. 1). The Meskwaki Settlement is in the central part of the basin near Tama.

Average annual precipitation in the Middle Iowa River Basin has been steadily increasing since the 1930s (fig. 2) The National Oceanic and Atmospheric Administration average long-term normal (1981-2010) precipitation of the two climate regions (5 and 6) that contain the Middle Iowa River Basin was 36.0 inches (in.) (Midwestern Regional Climate Center, 2015). Average annual precipitation in the Middle Iowa River Basin during 1980-96 was 35.1 in.; during 2006-10, 43.0 in.; and during 2011-18, 37.0 in. Streamflow almost doubles from inflow into the Middle Iowa River Basin measured at Marshalltown compared to that flowing into the Coralville Reservoir measured at Marengo (U.S. Geological Survey, 2019).

\section{Methods}

Data were aggregated from Federal, State, and Tribal agency sampling programs (U.S. Environmental Protection Agency, 2016; Iowa Department of Natural Resources, 2019; National Water Quality Monitoring Council, 2019; U.S. Geological Survey, 2019). Water-quality and biological data collected during 2006-07 from the Iowa River and tributaries in the vicinity of the Meskwaki Settlement are reported by Littin and McVay (2009).

\section{Aggregation of Streamflow and Nutrient Concentration Data}

Nutrient concentration data were aggregated to describe typical concentrations (average and maximum) in the Iowa River and tributary streams. Total nitrogen is the sum of nitrate and total Kjeldahl nitrogen or the sum of dissolved nitrogen and particulate nitrogen. For the purposes of computing statistical summaries, concentrations less than the analytical reporting limit (censored values) or estimated values were treated as equivalent to the reported value, potentially causing slight positive bias in the computed mean, though the bias is expected to be minimal because censoring $(3.8,0.5$, and 1.6 percent for nitrate, total nitrogen, and total phosphorus, respectively) was not common in the dataset (Helsel and others, 2020). Samples from the Iowa River were grouped on the basis of location into the four sites - upstream and downstream from Marshalltown, Iowa, near Tama, Iowa, and near Marengo, Iowa (table 1). The sizes of drainage areas of combined sites are within 7 percent of each other. Iowa River nutrient concentrations were related

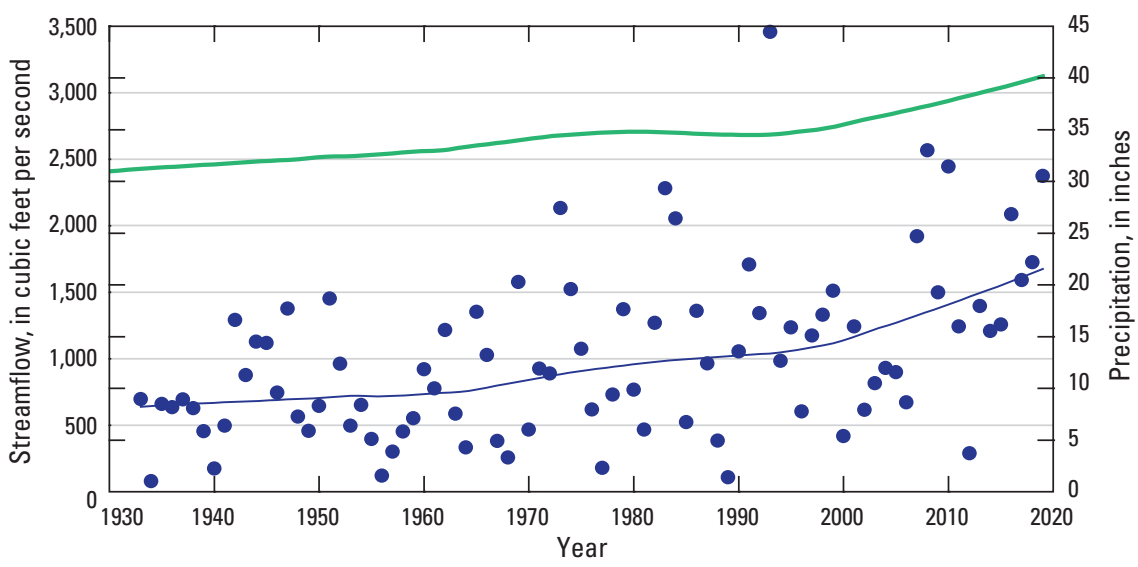

EXPLANATION

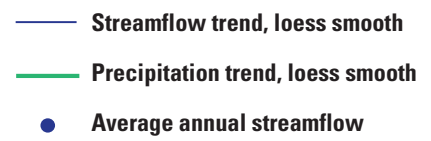

Figure 2. Long-term annual average streamflow in the lowa River at Marshalltown, lowa, in relation to annual precipitation in the Upper lowa River Basin. Annual precipitation is the average of that from lowa Climate divisions 5 and 6 (Midwestern Regional Climate Center, 2015). 
Table 1. Description of lowa River nutrient sampling sites.

$\left[\mathrm{mi}^{2}\right.$, square mile; USGS, U.S. Geological Survey; 21IOWA, Iowa Department of Natural Resources surface water monitoring; IASNAPST, Iowa Department of Natural Resources watershed snapshots; 1117MBR, U.S. Environmental Protection Agency Region 7; NW, northwest]

\begin{tabular}{|c|c|c|c|}
\hline Station description & $\begin{array}{l}\text { Basin area } \\
\left(\mathrm{mi}^{2}\right)\end{array}$ & $\begin{array}{c}\text { Difference in basin area } \\
\text { from streamgage, in percent }\end{array}$ & Agency and site identifier \\
\hline \multicolumn{4}{|c|}{ lowa River upstream from Marshalltown, lowa, associated with USGS streamgage 05451500} \\
\hline \multirow{2}{*}{ County Road S75 at Marietta, Iowa } & & & USGS-05451460 \\
\hline & & & 21IOWA-10640003 \\
\hline \multirow{3}{*}{ North Center Street, near water works plant } & & & IASNAPST-964016 \\
\hline & & & USGS-05451490 \\
\hline & & & 21IOWA-340600 \\
\hline Highway 14 & 1,532 & 0.0 & 21IOWA-340585 \\
\hline \multicolumn{4}{|c|}{ lowa River downstream from Marshalltown, lowa, associated with USGS streamgage 05451500} \\
\hline \multirow[t]{2}{*}{ County Road E35 east of Marshalltown, Iowa } & 1,630 & 6.4 & 21IOWA-340520 \\
\hline & & & 21IOWA-10640002 \\
\hline \multicolumn{4}{|c|}{ lowa River near Tama, lowa, associated with USGS streamgage 05451770} \\
\hline $\begin{array}{l}\text { Near Three Bridges County Park, Marshall County, } \\
\text { Iowa }\end{array}$ & 1,780 & -5.4 & 21IOWA-383234 \\
\hline \multirow[t]{2}{*}{ County Road T37, 1 mile north of Le Grande, Iowa } & 1,790 & -4.9 & IASNAPST-964028 \\
\hline & & & 21IOWA-340440 \\
\hline E Avenue near Montour, Iowa & 1,840 & -2.2 & USGS-05451750 \\
\hline \multicolumn{4}{|c|}{ lowa River near Marengo, lowa, to upstream from Coralville Reservoir, associated with USGS streamgage 05453100} \\
\hline \multirow[t]{3}{*}{ County road V66 1 mile north of Marengo, Iowa } & 2,794 & 0.0 & 21IOWA-330720 \\
\hline & & & USGS-05453100 \\
\hline & & & 21IOWA-10480001 \\
\hline Highway 220 north of South Amana, Iowa & 2,840 & 1.6 & 21IOWA-330615 \\
\hline \multirow[t]{2}{*}{ Highway 1512 miles south of Amana, Iowa } & 2,864 & 2.5 & USGS-05453180 \\
\hline & & & 21IOWA-330540 \\
\hline \multirow{2}{*}{$\begin{array}{l}\text { Greencastle Avenue NW, county road W48 } 3.5 \text { miles } \\
\text { south of Swisher, Iowa }\end{array}$} & 2,960 & 5.9 & 21IOWA-784022 \\
\hline & & & 21IOWA-330210 \\
\hline
\end{tabular}


to streamflow (USGS streamgages 05451500,05451770 , and 05453100). For streamflows near Tama (streamgage 05451770) prior to the beginning of the record in 2011, the streamflow from the Marshalltown streamgage (05451500) was used and adjusted on the basis of a drainage area ratio of 1.228 (table 1). Combining water-quality data from multiple sources can provide important insights, but issues can arise related to inconsistent metadata (Sprague and others, 2017), multiple censoring levels (Helsel and others, 2020), or different sampling regimes, particularly for the purpose of load estimation (Jones and others, 2012; Lee and others, 2016).

Statistical summaries are presented for all data sources, but changes in sampling frequency, timing, or targeted objectives (for example, high flow versus base flow) can dramatically affect interpretation of comparisons among sites or through time. Data are grouped into three periods for analysis of temporal trends. The first period, 1980-96, corresponds to the Iowa baseline period against which progress on nutrient reduction strategies are evaluated (State of Iowa, 2018). This period also corresponds to that on which the 45-percent Gulf hypoxia nutrient reduction goal is based (Mississippi River/ Gulf of Mexico Watershed Nutrient Task Force, 2008). The second period, 2006-10, is also used by the Iowa NRS as a historical comparison period because it generally has a large amount of available data (Iowa Department of Agriculture and Land Stewardship and others, 2017). The third period, 2011-18, is the current period. It is important to contrast historic periods (1980-96 and 2006-10) where data are available for both periods to understand how the use of data from either period affects the assessment of progress toward load reduction goals in the most recent period (2011-18). However, because consistent data were rarely available, there is limited discussion of concentration trends through time for the sites near Marshalltown (upstream and downstream) only, which provide the most consistent data collection of the four locations with sampling and load computation on the Iowa River. Comparisons of concentrations among sites are limited to periods with at least 14 samples (excludes several instances with one sample result in the period) for each site and serve to establish that findings are consistent with general patterns at other sites, particularly the Iowa River near Tama, Iowa.

\section{Calculation of Load and Yield}

Daily nitrate, total nitrogen, and total phosphorus loads and yields were estimated using linear interpolation; weighted regression on time, discharge, and season (WRTDS); or LOAD ESTimator (LOADEST) at sites with enough sample data to support the load estimation methods (Runkel and others, 2004; Hirsch and De Cicco, 2015). Sample data from the four Iowa River sites in the Middle Iowa River Basin were used for calibration datasets for load estimation models. For linear interpolation, censored values were ascribed the value of one-half the detection limit, whereas WRTDS and LOADEST preserve and utilize censored values for computing loads (Runkel and others, 2004; Hirsch and De Cicco, 2015). Because a daily time step was used for load computation, multiple samples on the same day were excluded to avoid autocorrelation errors.

Linear interpolation of concentrations between sampling points is the method chosen by the state for computing nitrate loads for the purposes of the State NRS, but this method has been shown to be inappropriate for total phosphorus (Lee and others, 2016; Schilling and others, 2017; Iowa Department of Agriculture and Land Stewardship and others, 2020). Concentrations of nitrate were estimated for days between sampling using the "fillMissing" linear interpolation function in the smwrBase package (Lorenz, 2015), which is part of the USGS R library. Linear interpolation of concentration was limited to periods when samples were collected 45 days or less apart. Daily nitrate loads were then calculated from the interpolated daily nitrate concentration and the mean daily streamflow at the sampling site. The linear interpolation method provides less accurate estimates than other methods for nondissolved constituents, such as Kjeldahl nitrogen and total phosphorus (Lee and others, 2016).

Regression-based methods using streamflow as an independent variable can produce an accurate estimate of daily total nitrogen and total phosphorus concentrations and loads (Lee and others, 2016). WRTDS and LOADEST were used to estimate daily total nitrogen and total phosphorus concentrations and loads. Although LOADEST uses multiple linear-regression techniques to parameterize a fixed model, WRTDS uses weighting functions for a more flexible approach (Hirsch and De Cicco, 2015). WRTDS is less susceptible to load estimation bias errors, which can sometimes occur in LOADEST (Hirsch, 2014), but at the cost of a larger calibration data requirement (Lee and others, 2016). WRTDS was used, therefore, to compute total nitrogen and total phosphorus loads and to fill gaps in nitrate loads where linear interpolation was not used. Samples collected prior to 1980 (fig. 3) were included for load model calibration by WRTDS. Because of the rather extensive data requirements for WRTDS, LOADEST was used in cases where sufficient data were not available for the WRTDS model. The WRTDS computations used the EGRET package (Hirsch and De Cicco, 2015), and LOADEST was employed using the "rloadest" package in R (R Core Team, 2019).

LOADEST models were fitted using data in each period, plus 2 additional years at the beginning and end of the period, except for the most recent period (2011-18), which had only one additional year at the end. Models required a minimum of 20 samples for the simplest model using only the logarithm of daily streamflow or 30 samples for multivariable models. LOADEST model diagnostics were assessed and plots were visually inspected to verify (1) a relation exists between loads and explanatory variables, (2) model errors are independent and normally distributed, (3) multiple explanatory or independent variables are not highly correlated, and (4) estimated loads are unbiased. Model residuals were inspected for extreme values, which were investigated as potential 

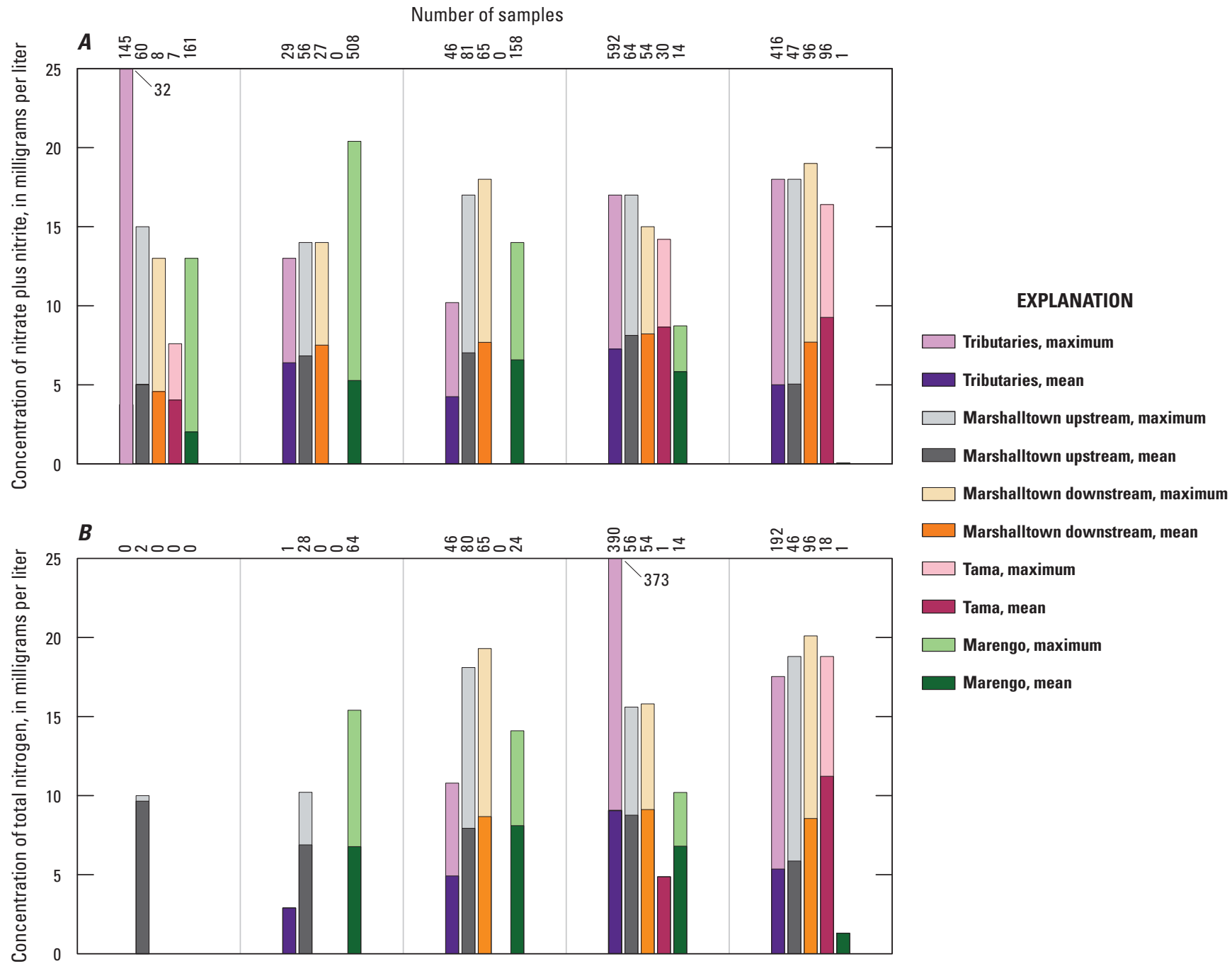

$\square$ Marshalltown downstream, mean

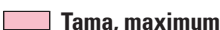

$\square$ Tama, mean

$\square$ Marengo, maximum

Marengo, mean

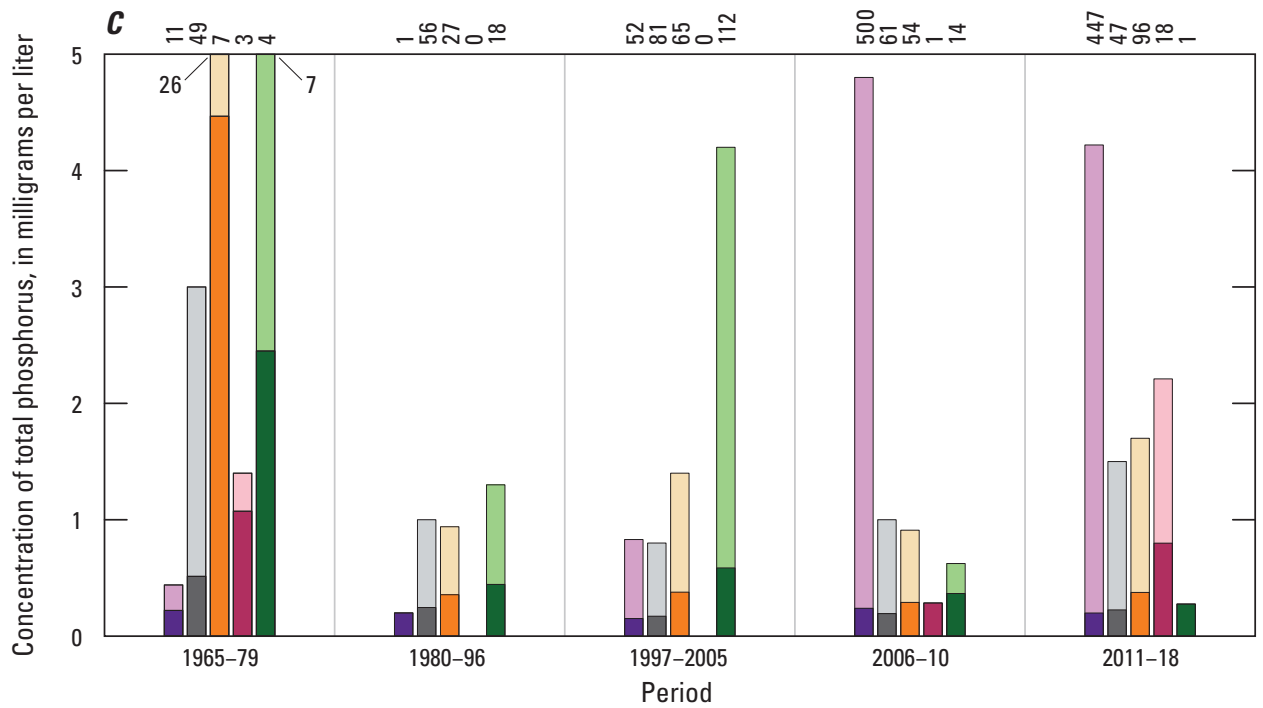

Figure 3. Nutrient concentrations in samples from the lowa River and tributary sites in the Middle lowa River Basin, upstream from Coralville Reservoir, lowa. $A$, nitrate plus nitrate; $B$, total nitrogen; and $C$, total phosphorus. Comparisons of concentrations among sites were considered only for periods with at least 14 samples for each site to lessen the effect of different sampling regimes. 
outliers. Rarely, outliers were removed from the calibration dataset only if they exhibited undue influence on model parameter (fitted coefficients) estimates and the problem could not be resolved by alternate selection of variables. Finally, LOADEST-computed loads were excluded where extrapolation was too severe, such as when streamflows or dates exceeded calibration data.

Annual nitrate, total nitrogen, and total phosphorus yields were calculated by dividing the annual load (in pounds) by the drainage area (in acres) at each site. Loads in the Iowa River upstream from Marshalltown represent loads transported from the Upper Iowa River Basin. Loads in the Iowa River at Marengo represent transport from the Upper and Middle Iowa River Basins upstream from the Coralville Reservoir. Annual loads and yield originating from the Middle Iowa River Basin (downstream load minus upstream input) were not calculated because data from the upstream site near Marshalltown and the downstream site near Marengo were not available from a concurrent period.

Unitized parameters for annual flow (runoff) and loads (yield) were calculated to allow for direct comparison of transport from different size basins during a range of dry to wet hydrologic conditions. Unitized parameters were used to document the relation between runoff and nutrient yield for each basin. Annual runoff is the total quantity of water that is discharged (runs off) from a drainage basin in a year. Runoff reported, in inches, refers to the depth to which the drainage area would be covered with water if all the runoff for a given period were distributed uniformly. Hydrologic conditions should be similar in basins having the same annual runoff regardless of size. Annual yield is the annual load, in pounds, divided by the drainage area, in acres, at the sampling site. The annual yield is the average for the entire basin and does not account for differences due to source or land use. Detailed quantification of yield from urban and agricultural sources is beyond the scope of this report. The runoff-yield relation is estimated by developing a linear regression with runoff as the independent variable and yield as the dependent variable. The regression is forced through the zero point because with no runoff there will be no transport or yield.

\section{lowa River Nutrient Concentrations, Loads, and Yields}

Annual and spring-to-summer (seasonal) nitrate, total nitrogen, and total phosphorus concentrations are presented in the following section for the Iowa River and tributaries upstream from the Coralville Reservoir during the periods 1980-96, 2006-10, 2011-18, and overall period 1980-2018. Loads and yields are presented for selected Iowa River sites and compared with other published loads and yields at sites within the study basin and at the Iowa River at Wapello, Iowa (Lee and others, 2017; Saad and others, 2019a,b; Schilling and others, 2020).

\section{Description of Nutrient Data}

Because data were aggregated from various programs, sampling data include periods of consistent (often monthly) data for several years, brief periods of frequent (daily or even subdaily) data, single-day data from many locations, or data from single samples targeting events such as hydrologic extremes (drought and flood). Though data from other Iowa River sites were combined where the basin area of the sampling sites were within 7 percent of the basin area at the streamflow gage, sites upstream and downstream from Marshalltown, Iowa, had dissimilar water chemistry, determined from paired data (samples collected on the same day) (table 1). For nitrate, total nitrogen, and total phosphorus, concentrations were greater ( $p$-value less than 0.05) downstream than upstream from Marshalltown, Iowa, overall (1980-2018) and for 1980-96, 2006-10, and 2011-18; the exception was nitrate during 1980-96 (difference was not significant). Paired data for nitrate at sites near Tama during 2006-18 were not significantly different. Other sites and constituents did not have enough paired sample data to assess site comparability.

Results of periodic monitoring at the four aggregated Iowa River sites in the Middle Iowa River Basin above the Coralville Reservoir (shown in fig. 1 as "Sampling and load sites") during 1980-2018 indicate overall average nitrate concentrations of 7.35 milligrams per liter $(\mathrm{mg} / \mathrm{L})$, average total nitrogen concentrations of $8.55 \mathrm{mg} / \mathrm{L}$, and average total phosphorus concentrations of $0.47 \mathrm{mg} / \mathrm{L}$ (table 2). Concentrations in samples from tributary sites were on average less, 6.24, 7.62 , and $0.22 \mathrm{mg} / \mathrm{L}$, respectively, for average nitrate, total nitrogen, and total phosphorus concentrations (table 2, fig. 3). Maximum Iowa River concentrations overall for nitrate, total nitrogen, and total phosphorus were 20.4, 20.1, and $4.2 \mathrm{mg} / \mathrm{L}$, respectively (table 2 ). Maximum concentrations in tributaries were similar for nitrate $(18.0 \mathrm{mg} / \mathrm{L})$ and total phosphorus $(4.8 \mathrm{mg} / \mathrm{L})$, but an outlier for total nitrogen was high, $373 \mathrm{mg} / \mathrm{L}$; the next highest tributary samples had $26.1 \mathrm{mg} / \mathrm{L}$. Samples collected prior to 1980 (fig. 3) were included for load model calibration, particularly by WRTDS. High streamflow samples are critical for load estimation but were not available for all constituents in all periods. For main-stem sites with at least 14 samples in a period (the minimum for comparison among sites), high streamflow samples were not available for total nitrogen upstream from Marshalltown (1980-96), nitrate near Tama (2006-10), and total phosphorus near Marengo (1980-96), which had a maximum sampled streamflow corresponding to the $60.3,71.9$, and 86.8 overall streamflow percentile, respectively (table 2 ). 
Table 2. Summary of nutrient concentrations in stream samples from the Middle lowa River Basin upstream from Coralville Reservoir, lowa, $1980-2018$.

[mg/L, milligrams per liter; $\mathrm{ft}^{3} / \mathrm{s}$, cubic feet per second; <, less than; --, not applicable]

\begin{tabular}{|c|c|c|c|c|c|c|c|c|c|c|}
\hline \multirow[b]{2}{*}{ Nutrient } & \multirow[b]{2}{*}{ Time period } & \multirow[b]{2}{*}{$\begin{array}{l}\text { Sample } \\
\text { count }\end{array}$} & \multicolumn{2}{|c|}{$\begin{array}{c}\text { Average concentration } \\
\text { (mg/L) }\end{array}$} & \multicolumn{2}{|c|}{$\begin{array}{c}\text { Maximum concentration } \\
\text { (mg/L) }\end{array}$} & \multicolumn{4}{|c|}{ Sampled streamflow } \\
\hline & & & $\begin{array}{c}\text { All } \\
\text { samples }\end{array}$ & $\begin{array}{l}\text { Spring- } \\
\text { summer }\end{array}$ & $\begin{array}{c}\text { All } \\
\text { samples }\end{array}$ & $\begin{array}{l}\text { Spring- } \\
\text { summer }\end{array}$ & $\begin{array}{l}\text { Mean } \\
\left(\mathrm{ft}^{3} / \mathrm{s}\right)\end{array}$ & $\begin{array}{l}\text { Maximum } \\
\left(\mathrm{ft}^{3} / \mathrm{s}\right)\end{array}$ & $\begin{array}{c}\text { Maximum, } \\
\text { percentile } \\
\text { within period }\end{array}$ & $\begin{array}{c}\text { Maximum, } \\
\text { overall percentile }\end{array}$ \\
\hline \multicolumn{11}{|c|}{ lowa River upstream from Marshalltown, lowa } \\
\hline \multirow{4}{*}{$\begin{array}{l}\text { Nitrate plus ni- } \\
\text { trite as nitrogen }\end{array}$} & $1980-96$ & 56 & 6.83 & 6.79 & 14.00 & 13.00 & 838 & 5,240 & 96.6 & 96.3 \\
\hline & $2006-10$ & 64 & 8.13 & 8.28 & 17.00 & 17.00 & 2,235 & 18,200 & 99.8 & 99.9 \\
\hline & $2011-18$ & 47 & 5.05 & 7.11 & 18.00 & 18.00 & 878 & 6,710 & 97.4 & 97.9 \\
\hline & $1980-2018$ & 245 & 6.89 & 7.71 & 18.00 & 18.00 & 1,201 & 18,200 & 99.9 & 99.9 \\
\hline \multirow[t]{4}{*}{ Total nitrogen } & 1980-96 & 28 & 6.88 & 7.18 & 10.21 & 9.30 & 563 & 916 & 62.4 & 60.3 \\
\hline & $2006-10$ & 56 & 8.76 & 9.03 & 15.60 & 15.60 & 2,050 & 18,200 & 99.8 & 99.9 \\
\hline & $2011-18$ & 46 & 5.86 & 8.03 & 18.80 & 18.80 & 878 & 6,710 & 97.4 & 97.9 \\
\hline & 1980-2018 & 210 & 7.56 & 8.70 & 18.80 & 18.80 & 1,130 & 18,200 & 99.9 & 99.9 \\
\hline \multirow[t]{4}{*}{ Total phosphorus } & $1980-96$ & 56 & 0.25 & 0.24 & 1.00 & 1.00 & 838 & 5,240 & 96.6 & 96.3 \\
\hline & $2006-10$ & 61 & 0.19 & 0.22 & 1.00 & 0.54 & 2,000 & 18,200 & 99.8 & 99.9 \\
\hline & 2011-18 & 47 & 0.23 & 0.23 & 1.50 & 0.98 & 878 & 6,710 & 97.4 & 97.9 \\
\hline & 1980-2018 & 242 & 0.20 & 0.23 & 1.50 & 1.00 & 1,130 & 18,200 & 99.9 & 99.9 \\
\hline \multicolumn{11}{|c|}{ lowa River downstream from Marshalltown, lowa } \\
\hline \multirow{4}{*}{$\begin{array}{l}\text { Nitrate plus ni- } \\
\text { trite as nitrogen }\end{array}$} & $1980-96$ & 27 & 7.51 & 7.44 & 14.00 & 13.00 & 1,120 & 5,240 & 96.6 & 96.3 \\
\hline & $2006-10$ & 54 & 8.22 & 8.24 & 15.00 & 15.00 & 1,650 & 11,400 & 99.1 & 99.6 \\
\hline & $2011-18$ & 96 & 7.70 & 8.56 & 19.00 & 19.00 & 1,400 & 7,710 & 98.1 & 98.5 \\
\hline & 1980-2018 & 242 & 7.79 & 8.41 & 19.00 & 19.00 & 1,290 & 11,400 & 99.6 & 99.6 \\
\hline \multirow[t]{4}{*}{ Total nitrogen } & $1980-96$ & 0 & -- & -- & -- & -- & -- & -- & -- & -- \\
\hline & $2006-10$ & 54 & 9.12 & 9.34 & 15.80 & 15.80 & 1,650 & 11,400 & 99.1 & 99.6 \\
\hline & 2011-18 & 96 & 8.55 & 9.49 & 20.10 & 20.10 & 13,400 & 7,710 & 98.1 & 98.5 \\
\hline & 1980-2018 & 215 & 8.73 & 9.61 & 20.10 & 20.10 & 1,310 & 11,400 & 99.6 & 99.6 \\
\hline \multirow[t]{4}{*}{ Total phosphorus } & 1980-96 & 27 & 0.36 & 0.38 & 0.94 & 0.94 & 1,120 & 5,240 & 96.6 & 96.3 \\
\hline & $2006-10$ & 54 & 0.29 & 0.30 & 0.91 & 0.76 & 1,650 & 11,400 & 99.1 & 99.6 \\
\hline & $2011-18$ & 96 & 0.38 & 0.32 & 1.70 & 1.10 & 1,400 & 7,710 & 98.1 & 98.5 \\
\hline & 1980-2018 & 242 & 0.35 & 0.33 & 1.70 & 1.10 & 1,290 & 11,400 & 99.6 & 99.6 \\
\hline
\end{tabular}


Table 2. Summary of nutrient concentrations in stream samples from the Middle lowa River Basin upstream from Coralville Reservoir, lowa, 1980-2018.-Continued [mg/L, milligrams per liter; ft3/s, cubic feet per second; $<$, less than; --, not applicable]

\begin{tabular}{|c|c|c|c|c|c|c|c|c|c|c|}
\hline Nutrient & Time period & $\begin{array}{l}\text { Sample } \\
\text { count }\end{array}$ & \multicolumn{2}{|c|}{$\begin{array}{l}\text { Average concentration } \\
(\mathrm{mg} / \mathrm{L})\end{array}$} & \multicolumn{2}{|c|}{$\begin{array}{l}\text { Maximum concentration } \\
(\mathrm{mg} / \mathrm{L})\end{array}$} & \multicolumn{4}{|c|}{ Sampled streamflow } \\
\hline \multirow{4}{*}{$\begin{array}{l}\text { Nitrate plus ni- } \\
\text { trite as nitrogen }\end{array}$} & $1980-96$ & 0 & -- & -- & -- & -- & -- & -- & -- & -- \\
\hline & $2006-10$ & 30 & 8.65 & 8.30 & 14.20 & 14.20 & 971 & 1,732 & 61.5 & 71.9 \\
\hline & 2011-18 & 96 & 9.27 & 9.55 & 16.40 & 16.40 & 2,560 & 12,100 & 99.1 & 99.4 \\
\hline & 1980-2018 & 126 & 9.12 & 9.29 & 16.40 & 16.40 & 2,180 & 12,100 & 99.4 & 99.4 \\
\hline \multirow[t]{4}{*}{ Total nitrogen } & $1980-96$ & 0 & -- & -- & -- & -- & -- & -- & -- & -- \\
\hline & $2006-10$ & 1 & 4.87 & 4.87 & 4.87 & 4.87 & 461 & 461 & 9.7 & 33.4 \\
\hline & $2011-18$ & 18 & 11.22 & 12.59 & 18.80 & 18.80 & 2,540 & 6,500 & 95.8 & 96.3 \\
\hline & $1980-2018$ & 19 & 10.89 & 12.11 & 18.80 & 18.80 & 2,430 & 6,500 & 96.3 & 96.3 \\
\hline \multirow[t]{4}{*}{ Total phosphorus } & 1980-1996 & 0 & -- & -- & -- & -- & -- & -- & -- & -- \\
\hline & 2006-2010 & 1 & 0.29 & 0.29 & 0.29 & 0.29 & 461 & 461 & 9.7 & 33.4 \\
\hline & 2011-2018 & 18 & 0.80 & 0.79 & 2.21 & 2.21 & 2,540 & 6,500 & 95.8 & 96.3 \\
\hline & $1980-2018$ & 19 & 0.77 & 0.75 & 2.21 & 2.21 & 2,430 & 6,500 & 96.3 & 96.3 \\
\hline \multicolumn{11}{|c|}{ lowa River near Marengo, lowa } \\
\hline \multirow{4}{*}{$\begin{array}{l}\text { Nitrate plus ni- } \\
\text { trite as nitrogen }\end{array}$} & $1980-96$ & 508 & 5.27 & 5.21 & 20.4 & 20.4 & 2,350 & 27,000 & 99.9 & 99.9 \\
\hline & $2006-10$ & 14 & 5.83 & 5.78 & 8.73 & 8.73 & 10,850 & 44,000 & 99.9 & 100.0 \\
\hline & $2011-18$ & 1 & $<0.04$ & $<0.04$ & $<0.04$ & $<0.04$ & 171 & 171 & 8.4 & 4.9 \\
\hline & $1980-2018$ & 681 & 5.58 & 5.64 & 20.4 & 20.4 & 2,580 & 44,000 & 100.0 & 100.0 \\
\hline \multirow[t]{4}{*}{ Total nitrogen } & $1980-96$ & 64 & 6.78 & 7.01 & 15.4 & 15.4 & 3,910 & 25,600 & 99.9 & 99.8 \\
\hline & $2006-10$ & 14 & 6.80 & 6.87 & 10.2 & 10.2 & 10,850 & 44,000 & 99.9 & 100.0 \\
\hline & $2011-18$ & 1 & 1.30 & 1.30 & 1.30 & 1.30 & 171 & 171 & 8.4 & 4.9 \\
\hline & $1980-2018$ & 103 & 7.04 & 7.30 & 15.4 & 15.4 & 4,740 & 44,000 & 100.0 & 100.0 \\
\hline \multirow[t]{4}{*}{ Total phosphorus } & $1980-96$ & 18 & 0.44 & 0.53 & 1.30 & 1.30 & 1,390 & 4,720 & 86.8 & 86.8 \\
\hline & $2006-10$ & 14 & 0.37 & 0.41 & 0.62 & 0.62 & 10,850 & 44,000 & 99.9 & 100.0 \\
\hline & 2011-18 & 1 & 0.28 & 0.28 & 0.28 & 0.28 & 171 & 171 & 8.4 & 4.9 \\
\hline & $1980-2018$ & 145 & 0.55 & 0.58 & 4.20 & 4.20 & 3,120 & 44,000 & 100.0 & 100.0 \\
\hline
\end{tabular}


[mg/L, milligrams per liter; $\mathrm{ft} 3 / \mathrm{s}$, cubic feet per second; <, less than; --, not applicable]

\begin{tabular}{|c|c|c|c|c|c|c|c|c|c|c|}
\hline \multirow[b]{2}{*}{ Nutrient } & \multirow[b]{2}{*}{ Time period } & \multirow{2}{*}{$\begin{array}{l}\text { Sample } \\
\text { count }\end{array}$} & \multicolumn{2}{|c|}{$\begin{array}{c}\text { Average concentration } \\
(\mathrm{mg} / \mathrm{L})\end{array}$} & \multicolumn{2}{|c|}{$\begin{array}{l}\text { Maximum concentration } \\
(\mathrm{mg} / \mathrm{L})\end{array}$} & \multicolumn{4}{|c|}{ Sampled streamflow } \\
\hline & & & $\begin{array}{c}\text { All } \\
\text { samples }\end{array}$ & $\begin{array}{l}\text { Spring- } \\
\text { summer }\end{array}$ & $\begin{array}{c}\text { All } \\
\text { samples }\end{array}$ & $\begin{array}{l}\text { Spring- } \\
\text { summer }\end{array}$ & $\begin{array}{l}\text { Mean } \\
\left(\mathrm{ft}^{3} / \mathrm{s}\right)\end{array}$ & $\begin{array}{l}\text { Maximum } \\
\left(\mathrm{ft}^{3} / \mathrm{s}\right)\end{array}$ & $\begin{array}{c}\text { Maximum, } \\
\text { percentile } \\
\text { within period }\end{array}$ & $\begin{array}{l}\text { Maximum, overall } \\
\text { percentile }\end{array}$ \\
\hline \multicolumn{11}{|c|}{ Summary of lowa River Sites } \\
\hline \multirow{4}{*}{$\begin{array}{l}\text { Nitrate plus ni- } \\
\text { trite as nitrogen }\end{array}$} & $1980-96$ & -- & 6.54 & 6.48 & 20.40 & 20.40 & -- & -- & -- & -- \\
\hline & $2006-10$ & -- & 7.71 & 7.65 & 17.00 & 17.00 & -- & -- & -- & -- \\
\hline & $2011-18$ & -- & 7.34 & 8.41 & 19.00 & 19.00 & -- & -- & -- & -- \\
\hline & 1980-2018 & -- & 7.35 & 7.76 & 20.40 & 20.40 & -- & -- & -- & -- \\
\hline \multirow[t]{4}{*}{ Total nitrogen } & $1980-96$ & -- & 6.83 & 7.09 & 15.40 & 15.40 & -- & -- & -- & -- \\
\hline & $2006-10$ & -- & 7.39 & 7.53 & 15.80 & 15.80 & -- & -- & -- & -- \\
\hline & $2011-18$ & -- & 6.73 & 7.85 & 20.10 & 20.10 & -- & -- & -- & -- \\
\hline & 1980-2018 & -- & 8.55 & 9.43 & 20.10 & 20.10 & -- & -- & -- & -- \\
\hline \multirow[t]{4}{*}{ Total phosphorus } & $1980-96$ & -- & 0.35 & 0.38 & 1.30 & 1.30 & -- & -- & -- & -- \\
\hline & 2006-10 & -- & 0.28 & 0.30 & 1.00 & 0.76 & -- & -- & -- & -- \\
\hline & 2011-18 & -- & 0.42 & 0.40 & 2.21 & 2.21 & -- & -- & -- & -- \\
\hline & 1980-2018 & -- & 0.47 & 0.47 & 4.20 & 4.20 & -- & -- & -- & -- \\
\hline \multicolumn{11}{|c|}{ Tributary sites } \\
\hline \multirow{4}{*}{$\begin{array}{l}\text { Nitrate plus ni- } \\
\text { trite as nitrogen }\end{array}$} & 1980-96 & 29 & 6.40 & 6.97 & 13.00 & 13.00 & -- & -- & -- & -- \\
\hline & 2006-10 & 592 & 7.26 & 7.49 & 17.00 & 17.00 & -- & -- & -- & -- \\
\hline & $2011-18$ & 416 & 5.00 & 5.48 & 18.00 & 18.00 & -- & -- & -- & -- \\
\hline & 1980-2018 & 1,083 & 6.24 & 6.57 & 18.00 & 18.00 & -- & -- & -- & -- \\
\hline \multirow[t]{4}{*}{ Total nitrogen } & $1980-96$ & 1 & 2.90 & 2.90 & 2.90 & 2.90 & -- & -- & -- & -- \\
\hline & $2006-10$ & 390 & 9.06 & 8.40 & 373.0 & 26.10 & -- & -- & -- & -- \\
\hline & 2011-18 & 192 & 5.36 & 6.20 & 17.53 & 17.53 & -- & -- & -- & -- \\
\hline & 1980-2018 & 629 & 7.62 & 7.52 & 373.0 & 26.10 & -- & -- & -- & -- \\
\hline \multirow[t]{4}{*}{ Total phosphorus } & $1980-96$ & 1 & 0.20 & 0.20 & 0.20 & 0.20 & -- & -- & -- & -- \\
\hline & 2006-10 & 500 & 0.24 & 0.27 & 4.80 & 4.80 & -- & -- & -- & -- \\
\hline & 2011-18 & 447 & 0.20 & 0.20 & 4.22 & 4.22 & -- & -- & -- & -- \\
\hline & 1980-2018 & 1,000 & 0.22 & 0.23 & 4.80 & 4.80 & -- & -- & -- & -- \\
\hline
\end{tabular}


At the sites upstream and downstream from Marshalltown, Iowa, the average nitrate, total nitrogen, and total phosphorus concentrations during the historical comparison period 1980-96 were less than those for 2006-10 (table 2). Average nitrate concentrations were 6.83 and $7.51 \mathrm{mg} / \mathrm{L}$ for all samples during 1980-96 compared to 8.13 and $8.22 \mathrm{mg} / \mathrm{L}$ during $2006-10$, at the upstream and downstream sites, respectively. Average total nitrogen concentrations at the upstream site increased from 6.88 to $8.76 \mathrm{mg} / \mathrm{L}$ for all samples from 1980-96 to 2006-10. Total nitrogen samples were not available for the downstream site for the 1980-96 period, but the average total nitrogen concentration for all samples in 2006-10 was $9.12 \mathrm{mg} / \mathrm{L}$. Average total phosphorus concentrations were 0.25 and $0.36 \mathrm{mg} / \mathrm{L}$ for all samples during 1980-96 compared to 0.19 and $0.29 \mathrm{mg} / \mathrm{L}$ during $2006-10$ for the upstream and downstream sites, respectively.

Relative to either historical period, nitrate and total nitrogen concentrations decreased during the most recent period (2011-18) for Iowa River sites upstream from Marshalltown, Iowa, though this trend does not hold for downstream sites and may be driven by changes in sampling frequency (discontinuation of routine sampling at upstream site in 2014). For the upstream and downstream sites, average nitrate concentrations for 2011-18 were 5.05 and $7.70 \mathrm{mg} / \mathrm{L}$, respectively; total nitrogen, 5.86 and $8.55 \mathrm{mg} / \mathrm{L}$; and total phosphorus, 0.23 and $0.38 \mathrm{mg} / \mathrm{L}$ (table 2).

To lessen the effect of different sampling regimes, comparisons of concentrations among sites were considered only for periods with at least 14 samples for each site and primarily serve to establish whether findings were consistent with trends at other sites, in particular to the Iowa River near Tama, Iowa, site. Sampling at Tama was more focused on spring and summer than sampling at other sites, and though spring-summer concentrations were generally greater than all-sample averages for all constituents, relations among sites using all-sample or seasonal averages were consistent (table 2). Average nitrate and total nitrogen concentrations tended to increase from upstream to downstream from Marshalltown then decrease at Marengo (fig. 3). Nitrate and total nitrogen concentrations at Tama, available only for the two later periods, were generally greater than those for the Marshalltown sites. Average total phosphorus concentrations tended to increase from upstream to downstream at all sites in the Iowa River, though same-period comparisons were not available for Tama versus Marengo.

Nitrate and total nitrogen concentrations were more strongly related to streamflow than were total phosphorus concentrations, although the relation was generally nonmonotonic (fig. 4). Nitrate and total nitrogen concentrations tended to increase with streamflow through moderately high streamflow, then remain consistent or decrease at very high streamflow. Total phosphorus concentrations were generally greatest at low and high streamflows, except concentrations near Marengo, which were consistent over the range of streamflow.

\section{Annual and Seasonal Nutrient Loads}

Average annual and seasonal loads are presented for 1980-96, 2006-10, and 2011-18 in table 3. Even with estimates combined from these methods, load estimates could not be computed for all sites, years, and constituents. Loads from Iowa River upstream from Marshalltown, Iowa, represent nutrients transported into the Middle Iowa River Basin from the Upper Iowa River Basin, and loads near Marengo represent nutrients transported out of the study area into Coralville Reservoir. Few loads or yields within the study basin have been previously reported, and additional estimates are referenced as yields for better comparison with basins of different sizes for the South Fork Iowa River northeast of New Providence, Iowa, (USGS station 05451210, basin area $224 \mathrm{mi}^{2}$ ) and the Iowa River at Wapello, Iowa (USGS station 05465500, basin area 12,500 $\mathrm{mi}^{2}$ ).

Because data were not available as a basis for historical loads in the Iowa River near Tama, Iowa, historical loads were estimated for nitrate as a range based on loads at the two sites near Marshalltown, Iowa, adjusted by drainage ratio (multiplied by 1.289 or 1.155 ). The downstream site is closer to Tama, but the record is more complete at the upstream site. Although this provides a reference for calculated nitrate loads during 2011-18, this range for historical reference at Tama is likely underestimated because average sampled concentrations at Tama were higher than at either site near Marshalltown. Some of the increase in nitrate concentrations at Tama relative to upstream sites may be attributed to seasonal differences because seasonal (spring and summer) average concentrations were generally greater than annual averages (table 2), and sampling at Tama was focused on spring and summer periods.

Nitrate loads in the Iowa River during both historical reference periods (1980-96 and 2006-10) were generally smaller upstream from Marshalltown, Iowa, than at other sites, with a minimum historical period load among all sites of 13,800 tons per year (ton/yr) upstream from Marshalltown, Iowa, during 1980-96. The maximum historical period nitrate load, 20,000 ton/yr during 2006-10, was determined for the site near Marengo, Iowa. Average annual nitrate yields during the historical periods were smallest near Marengo, 17.6 pounds per acre (lb/acre) during 1980-96, and greatest downstream from Marshalltown, Iowa, $34.2 \mathrm{lb}$ /acre during 1980-96. During the recent period, 2011-18, average yields ranged from $19.7 \mathrm{lb} /$ acre upstream from Marshalltown, Iowa, to $28.8 \mathrm{lb} /$ acre near Tama, although calculated yields were not available for all years in the period for the upstream site. Calculated nitrate loads were not available for the site near Tama for the historic periods and are presented as an estimated range of loads from Marshalltown sites times the drainage area ratio. Calculated nitrate loads were not available at Marengo during 2011-18. For comparison, average annual nitrate yields for the entire Iowa River Basin at Wapello, Iowa, were $20.1 \mathrm{lb} / \mathrm{acre}$ from 1978 to 2017 (Lee and others, 2017). 
Total nitrogen loads in the Iowa River during either historical reference period ranged from a period average of 15,600 tons per year (ton/yr) upstream from Marshalltown, Iowa, during 1980-96 to 31,600 ton/yr near Marengo, Iowa, during 2006-10 (table 3). Total nitrogen yields for all Iowa River sites during the historical periods ranged from 22.2 to $35.3 \mathrm{lb} / \mathrm{acre}$, both near Marengo, Iowa, during 1980-96 and 2006-10, respectively. In the recent period, 2011-18, average yields ranged from $17.7 \mathrm{lb} /$ acre upstream from Marshalltown, Iowa, to $24.5 \mathrm{lb}$ /acre downstream from Marshalltown, Iowa, though calculated yields were not available for all years in the period for the upstream site (table 3). Calculated total nitrogen loads were not available for the site near Tama during any period nor at Marengo during 2011-18. For comparison, average annual total nitrogen yields for the Iowa River at Wapello based on methods described by Lee and others (2017) were $23.7 \mathrm{lb} /$ acre for 1978-2018 (Lee and others, 2018), although Saad and others (2019a,b) report $17.6 \mathrm{lb} /$ acre for 1999-2014. Upstream from the study basin, yields for the South Fork Iowa
River were $28.4 \mathrm{lb} /$ acre for 1999-2014 and $24.8 \mathrm{lb} /$ acre for the Iowa River upstream from Marshalltown, Iowa (Saad and others, 2019a,b).

Total phosphorus loads in the Iowa River during either historical reference period ranged from an average of 456 tons per year (ton/yr) upstream from Marshalltown, Iowa, during 1980-96 to 1,880 ton/yr near Marengo, Iowa, during 2006-10. Yields for all Iowa River sites during the historical periods ranged from $0.977 \mathrm{lb} /$ acre upstream from Marshalltown, Iowa, during 1980-96 to $2.10 \mathrm{lb} /$ acre near Marengo, Iowa, during 2006-10. During the recent period, 2011-18, average yields ranged from $0.887 \mathrm{lb} /$ acre upstream from Marshalltown, Iowa, to $0.994 \mathrm{lb} /$ acre downstream from Marshalltown, Iowa, although calculated yields were not available for all years in the period for the upstream site. Calculated total phosphorus loads were not available for the site near Tama during any period, nor at Marengo for the 2011-18 period. For comparison, total phosphorus yields downstream from Marshalltown for years in all periods averaged $1.05 \mathrm{lb} /$ acre (range of 0.21 to
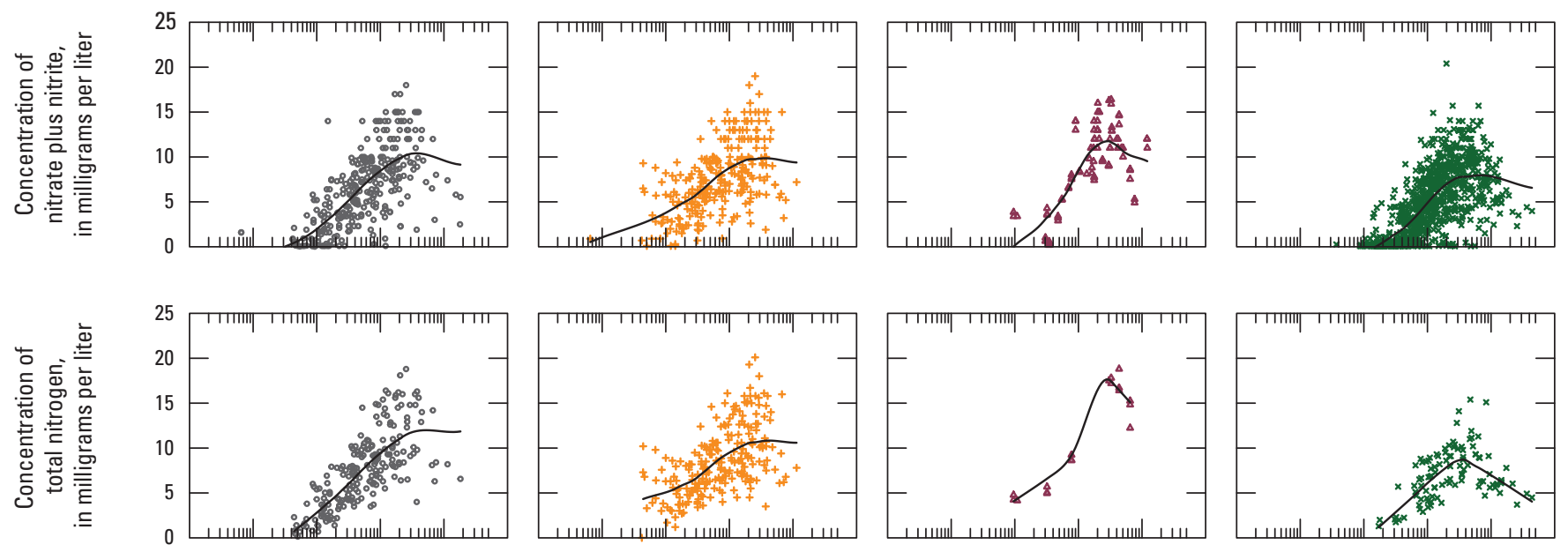

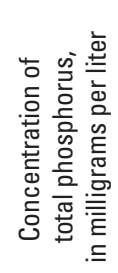
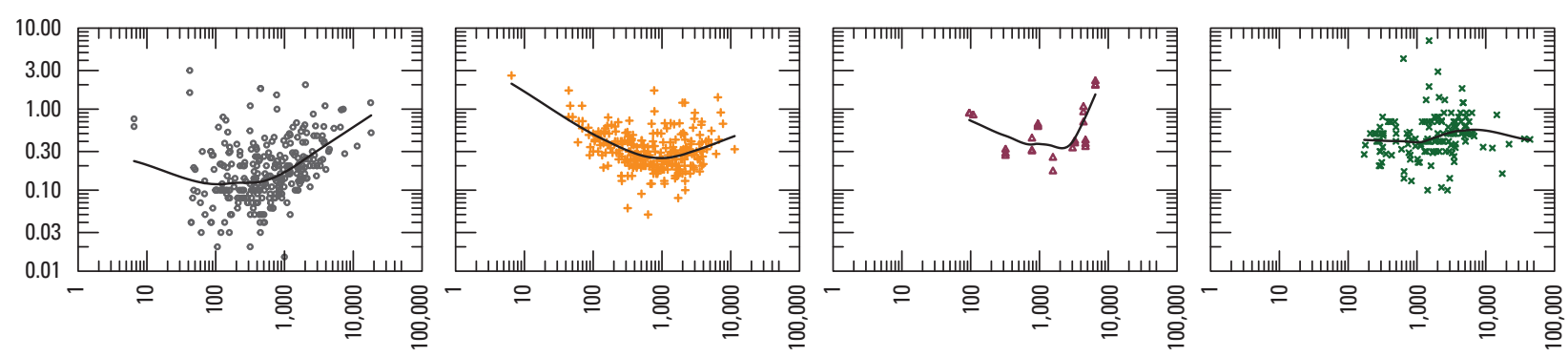

Streamflow, in cubic feet per second

\section{EXPLANATION}

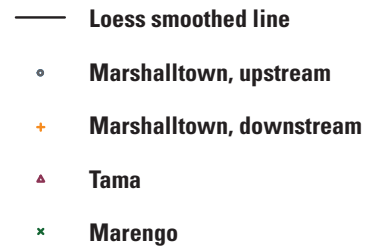

Figure 4. Relation between streamflow and nutrient concentrations in the lowa River with loess smoothed lines, 1980-2019. 
Table 3. Average annual and seasonal nutrient loads and yields for the Middle lowa River Basin upstream from Coralville Reservoir, $1980-2018$.

[--, no data or not applicable]

\begin{tabular}{|c|c|c|c|c|c|c|c|c|c|c|}
\hline \multirow{2}{*}{ Constituent } & \multirow{2}{*}{ Time period } & \multicolumn{2}{|c|}{ Average annual load } & \multirow{2}{*}{$\begin{array}{l}\text { Change } \\
\text { relative to } \\
2011-18\end{array}$} & \multicolumn{2}{|c|}{$\begin{array}{c}\text { Average spring-summer } \\
\text { load }\end{array}$} & \multirow{2}{*}{$\begin{array}{l}\text { Change } \\
\text { relative to } \\
2011-18\end{array}$} & \multicolumn{2}{|c|}{$\begin{array}{c}\text { Average Yield } \\
\text { (pounds per acre) }\end{array}$} & \multirow{2}{*}{$\begin{array}{l}\text { Ratio of spring- } \\
\text { summer relative } \\
\text { to annual }\end{array}$} \\
\hline & & Years & $\begin{array}{l}\text { Load } \\
\text { (tons) }\end{array}$ & & Years & $\begin{array}{l}\text { Load } \\
\text { (tons) }\end{array}$ & & Annual & $\begin{array}{l}\text { Spring- } \\
\text { summer }\end{array}$ & \\
\hline \multicolumn{11}{|c|}{ lowa River upstream from Marshalltown, lowa } \\
\hline \multirow{3}{*}{$\begin{array}{l}\text { Nitrate plus nitrite as } \\
\text { nitrogen }\end{array}$} & $1980-96$ & 17 & 13,800 & -33 & 17 & 7,970 & 4 & 29.5 & 17.1 & 0.58 \\
\hline & $2006-10$ & 5 & 13,900 & -34 & 5 & 9,920 & -16 & 29.8 & 21.2 & 0.71 \\
\hline & $2011-18$ & 4 & 9,200 & -- & 4 & 8,300 & -- & 19.7 & 17.8 & 0.90 \\
\hline \multirow[t]{3}{*}{ Total nitrogen } & $1980-96$ & 10 & 15,600 & -47 & 10 & 9,360 & -25 & 33.5 & 20.0 & 0.60 \\
\hline & $2006-10$ & 5 & 16,000 & -48 & 5 & 11,460 & -39 & 34.2 & 24.5 & 0.72 \\
\hline & $2011-18$ & 4 & 8,290 & -- & 4 & 6,990 & -- & 17.7 & 15.0 & 0.84 \\
\hline \multirow[t]{3}{*}{ Total phosphorus } & $1980-96$ & 17 & 456 & -9.2 & 17 & 324 & 9 & 0.977 & 0.694 & 0.71 \\
\hline & $2006-10$ & 5 & 655 & -37 & 5 & 468 & -24 & 1.40 & 1.00 & 0.71 \\
\hline & 2011-18 & 4 & 415 & -- & 4 & 354 & -- & 0.887 & 0.76 & 0.85 \\
\hline \multicolumn{11}{|c|}{ lowa River downstream from Marshalltown, lowa } \\
\hline \multirow{3}{*}{$\begin{array}{l}\text { Nitrate plus nitrite as } \\
\text { nitrogen }\end{array}$} & 1980-96 & 7 & 17,800 & -23 & 7 & 11,500 & -13 & 34.2 & 22.0 & 0.64 \\
\hline & $2006-10$ & 5 & 16,200 & -14 & 5 & 11,400 & -13 & 31.0 & 21.9 & 0.71 \\
\hline & $2011-18$ & 8 & 13,800 & -- & 8 & 9,900 & -- & 26.5 & 19.1 & 0.72 \\
\hline \multirow[t]{3}{*}{ Total nitrogen } & 1980-96 & 0 & -- & -- & 0 & -- & -- & -- & -- & -- \\
\hline & $2006-10$ & 5 & 17,900 & -29 & 5 & 12,700 & -28 & 34.3 & 24.4 & 0.71 \\
\hline & $2011-18$ & 8 & 12,800 & -- & 8 & 9,200 & -- & 24.5 & 17.6 & 0.72 \\
\hline \multirow[t]{3}{*}{ Total phosphorus } & $1980-96$ & 7 & 573 & -9.5 & 7 & 372 & -4.4 & 1.10 & 0.714 & 0.65 \\
\hline & $2006-10$ & 5 & 743 & -30 & 5 & 485 & -27 & 1.42 & 0.930 & 0.65 \\
\hline & $2011-18$ & 8 & 519 & -- & 8 & 356 & -- & 0.994 & 0.682 & 0.69 \\
\hline \multicolumn{11}{|c|}{ lowa River near Tama, Iowa } \\
\hline \multirow{3}{*}{$\begin{array}{l}\text { Nitrate plus nitrite as } \\
\text { nitrogen }\end{array}$} & $1980-96$ & $(1)$ & $17,800-20,600$ & -16 to -2.4 & (1) & $10,300-13,200$ & -9.0 to 17 & $29.5-34.2$ & $17.1-22.0$ & $0.50-0.75$ \\
\hline & $2006-10$ & $(1)$ & $18,000-18,700$ & -7.1 to -3.6 & (1) & $12,800-13,200$ & -8.7 to -5.8 & $29.83-30.97$ & $21.2-22.0$ & $0.69-0.73$ \\
\hline & 2011-18 & 8 & 17,300 & -- & 8 & 12,000 & -- & 28.8 & 20.0 & 0.70 \\
\hline \multicolumn{11}{|c|}{ lowa River near Marengo, lowa } \\
\hline \multirow{3}{*}{$\begin{array}{l}\text { Nitrate plus nitrite as } \\
\text { nitrogen }\end{array}$} & $1980-96$ & 17 & 15,700 & -- & 17 & 10,400 & -- & 17.6 & 11.6 & 0.66 \\
\hline & $2006-10$ & 5 & 20,000 & -- & 5 & 14,400 & -- & 22.4 & 16.1 & 0.72 \\
\hline & $2011-18$ & 0 & -- & -- & 0 & -- & -- & -- & -- & -- \\
\hline
\end{tabular}


[--, no data or not applicable]

\begin{tabular}{|c|c|c|c|c|c|c|c|c|c|c|}
\hline \multirow{2}{*}{ Constituent } & \multirow{2}{*}{ Time period } & \multicolumn{2}{|c|}{ Average annual load } & \multirow{2}{*}{$\begin{array}{l}\text { Change } \\
\text { relative to } \\
2011-18\end{array}$} & \multicolumn{2}{|c|}{$\begin{array}{c}\text { Average spring-summer } \\
\text { load }\end{array}$} & \multirow{2}{*}{$\begin{array}{l}\text { Change } \\
\text { relative to } \\
2011-18\end{array}$} & \multicolumn{2}{|c|}{$\begin{array}{c}\text { Average Yield } \\
\text { (pounds per acre) }\end{array}$} & \multirow{2}{*}{$\begin{array}{l}\text { Ratio of spring- } \\
\text { summer relative } \\
\text { to annual }\end{array}$} \\
\hline & & Years & $\begin{array}{l}\text { Load } \\
\text { (tons) }\end{array}$ & & Years & $\begin{array}{l}\text { Load } \\
\text { (tons) }\end{array}$ & & Annual & $\begin{array}{l}\text { Spring- } \\
\text { summer }\end{array}$ & \\
\hline \multirow[t]{3}{*}{ Total nitrogen } & 1980-96 & 5 & 19,900 & -- & 5 & 14,200 & -- & 22.2 & 15.9 & 0.72 \\
\hline & 2006-10 & 3 & 31,600 & -- & 3 & 20,000 & -- & 35.3 & 22.3 & 0.63 \\
\hline & $2011-18$ & 0 & -- & -- & 0 & -- & -- & -- & -- & -- \\
\hline \multirow[t]{3}{*}{ Total phosphorus } & $1980-96$ & 1 & 928 & -- & 1 & 629 & -- & 1.04 & 0.703 & 0.68 \\
\hline & $2006-10$ & 3 & 1,880 & -- & 3 & 1,290 & -- & 2.10 & 1.45 & 0.69 \\
\hline & $2011-18$ & 0 & -- & -- & 0 & -- & -- & -- & -- & -- \\
\hline
\end{tabular}

${ }^{1}$ Loads for historical reference periods at Tama computed as a range of loads from Marshalltown sites times drainage area ratio. 
$2.12 \mathrm{lb} / \mathrm{acre})$, compared to $0.89 \mathrm{lb} / \mathrm{acre}(0.21$ to $2.04 \mathrm{lb} / \mathrm{acre})$ reported by Schilling and others (2020) for 2000-17. For the Iowa River at Wapello for 1978-2018, average annual total phosphorus yields were $0.95 \mathrm{lb} / \mathrm{acre}$ (Lee and other, 2017) or $0.89 \mathrm{lb} /$ acre for 1999-2014 (Saad and others, 2019a,b). Upstream from the study basin, yields from the South Fork Iowa River, a tributary to the Iowa River, were $0.99 \mathrm{lb} / \mathrm{acre}$ for 1999-2014 and $0.89 \mathrm{lb} /$ acre for the Iowa River upstream from Marshalltown, Iowa (Saad and others, 2019a,b).

As with concentration, inconsistencies in the number of years with computed loads challenges comparison among sites and periods. Also, as with concentrations and although loads tended to increase through the entire reach of the Iowa River, nutrient yields tended to increase from upstream from Marshalltown to Tama, then decrease near Marengo (table 3, fig. 5). Additional research would be needed to assess the mechanism of the lesser yields, such as dilution or flood plain processes like attenuation of streamflow peaks, denitrification, and deposition. Within-basin contributions were not assessed, but overall nitrate and total nitrogen concentrations, though lower than at upstream sites, were not as low as concentrations at Marengo (table 2), indicating simple dilution alone would not sufficiently reduce yields to values observed near Marengo. Flood plain connectivity has been shown to reduce nutrient loads, particularly in natural backwaters (for example, Kiedrzyńska and others, 2008; Loken and others, 2018).

The averaged changes in loads calculated for the site upstream from Marshalltown, Iowa, were reductions of 34 percent for nitrate, 48 percent for total nitrogen, and 37 percent for total phosphorus, relative to the later comparison period (2006-10, table 3). Average reductions upstream from Marshalltown, Iowa, were similar relative to the earlier period (1980-96), except for total phosphorus, which had only a 9-percent difference. Loads downstream from Marshalltown also were less than the historical comparison periods, though with a smaller reduction than upstream, for example, 14-, 29-, and 30-percent average reductions for nitrate, total nitrogen, and total phosphorus, respectively, relative to 2006-10 (table 3). The comparison of load reductions upstream and downstream from Marshalltown was confounded, however, by differences in available data because the upstream loads include 2011-14 data, and downstream loads include 2011-18 data. Reductions near Tama-loads were computed only for nitrate - were at least 2-16 percent, though the average reduction is likely underestimated because of the uncertainty in the historical comparison loads. The historical-period loads computed near Tama were based on historical loads downstream from Marshalltown, which had lower average concentrations and less seasonally focused sampling than Tama. Loads during historical periods were computed for Marengo but there was insufficient data in 2011-18 to assess reductions.

Despite upward trends in precipitation and streamflow (fig. 2), average loads for nitrate, total nitrogen, and total phosphorus were lower for 2011-18 than for the historical comparison periods. Reductions in average loads for 2011-18 may not represent a sustained trend, but rather may indicate interannual variability in loads (fig. 6). Loads for all constituents were much less in 2012 than the rest of the 2011-18 period owing to notable drought conditions (fig. 2). Average nitrate loads, for example, in the last 5 years of the period at the site downstream from Marshalltown, Iowa, were only 9 percent less than the historical comparison loads (fig. 6). Differences in high-flow and base-flow trends may affect seasonal and annual loads differently. Although trends were upward for annual streamflow (fig. 2) and low flows ( $p$-value less than 0.05 for annual and 7-day minimum flows, Mann-Kendall test), trends for high flows were not significant ( $p$-value greater than 0.05 for water-year maximum, Mann-Kendall).

A disproportionate amount of the annual loads was transported in the spring and summer (April-September), at least 50 percent to as much as 90 percent (table 3 ). Although this is not surprising, given generally greater seasonal streamflow, it is important to determine whether seasonal monitoring would detect similar changes as annual load estimates (that is, if seasonal monitoring gives similar results for relative load reductions). Upstream from Marshalltown, average reductions in seasonal loads relative to 2006-10 were 16 percent for nitrate, 39 percent for total nitrogen, and 24 percent for total phosphorus (table 3). Relative to 1980-96, the difference was +4 percent, -25 percent and +9 percent for nitrate, total nitrogen, and total phosphorus, respectively (table 3 ), with positive indicating an increase in loads and negative indicating a decrease in loads. Though seasonal differences relative to the 2006-10 are more consistent with the annual reduction estimates, one reason for load reduction targets is to reduce the zone of hypoxia in the Gulf of Mexico to pre-1990s conditions. The inconsistent seasonal trends using the different reference periods may be driven by streamflow trends, particularly by the upward trend in base flow.

Though load-reduction strategies are based on annual computations, the relevant issues for nutrients highlight concerns particularly during spring and summer. Downstream hypoxia has been linked to spring total nitrogen transport from the Midwest; nitrate concentrations greater than drinking water standards often occur during these seasons. Targets for reduction in size of the Gulf of Mexico hypoxic zone are based on reference conditions in the 1980s and 1990s.

Annual loads when used with annual streamflow can be used to calculate the relation between basin runoff and nutrient yield. Runoff transport relations are an additional tool to evaluate progress of nutrient reduction (Kalkhoff, 2018) efforts in the basin. A uniform reduction in yield over a range of streamflow conditions will result in a lower slope of the trend line (fig. 7). Although it is important to assess the reduction of loads overall, runoff-transport relations can be used to control for effects of interannual streamflow variability or trends. At very high flows, however, the yield-runoff relation becomes non-linear for nitrate. This may indicate that there is a limited amount of nitrate available in the basin for transport. 

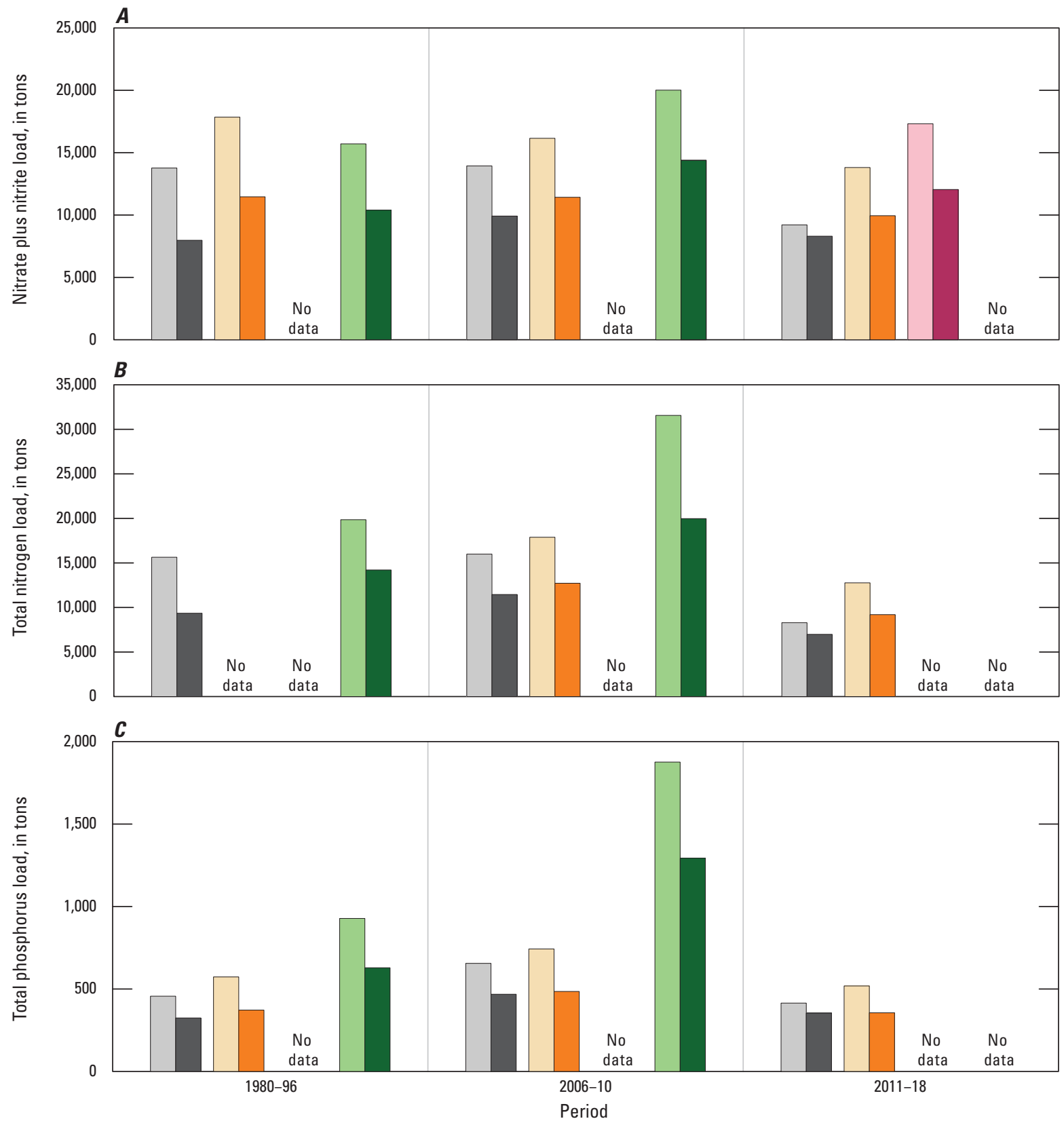

EXPLANATION

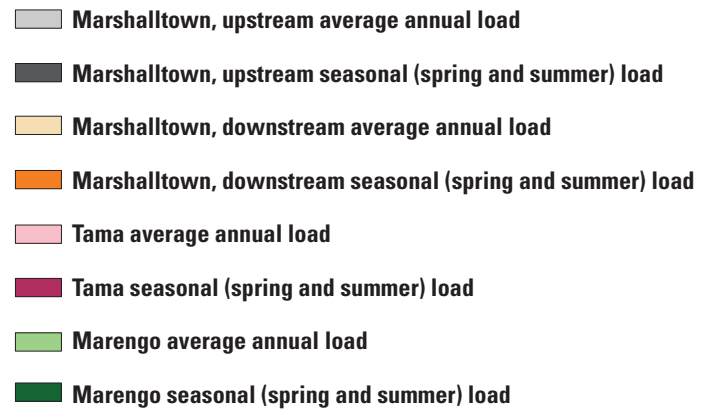

Figure 5. Nutrient loads in the Middle lowa River Basin, upstream from Coralville Reservoir, lowa, 1980-2018. $A$, nitrate plus nitrite; $B$, total nitrogen; and $C$, total phosphorus. 


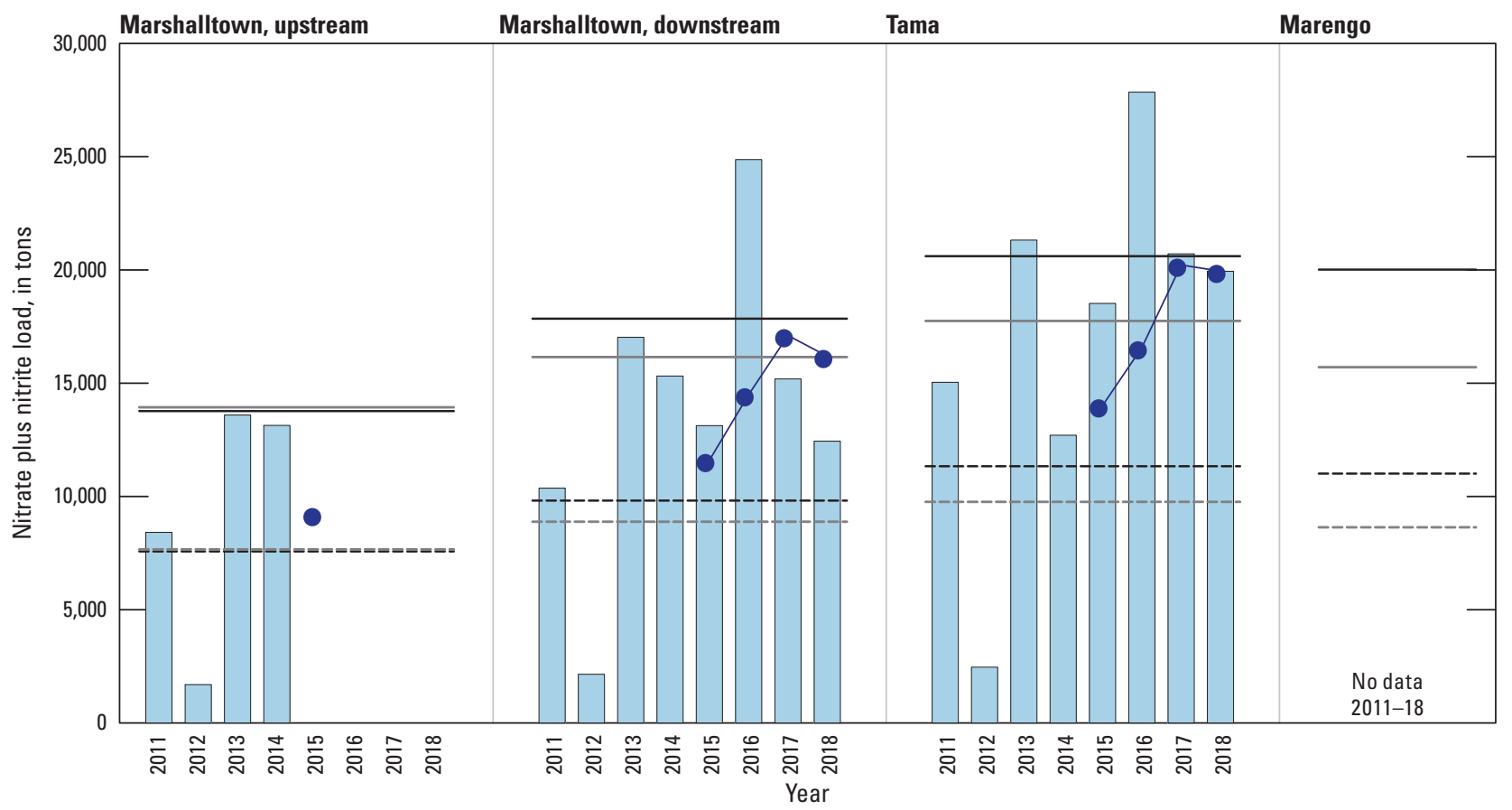

EXPLANATION

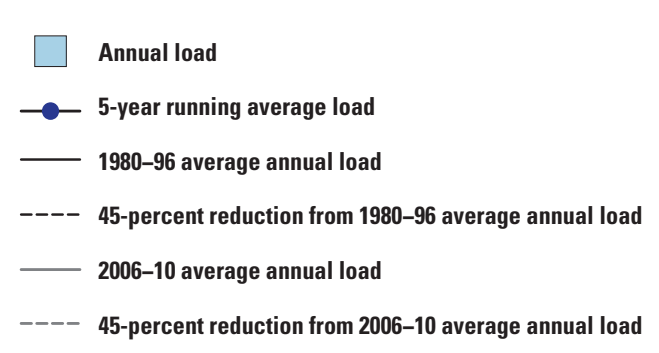

Figure 6. Annual nitrate loads in the lowa River, 2011-18, with running average of the preceding 5 years relative to average loads from historical comparison periods 1980-96 and 2006-10 and 45-percent reduction of the historical loads. Reference lines for Tama are likely underestimated because they are based on historical loads downstream from Marshalltown, which had lower average concentrations and less seasonally focused sampling than Tama. Reference lines for Marengo are provided for comparison with the other sites, though loads were not computed at this site during the period. 

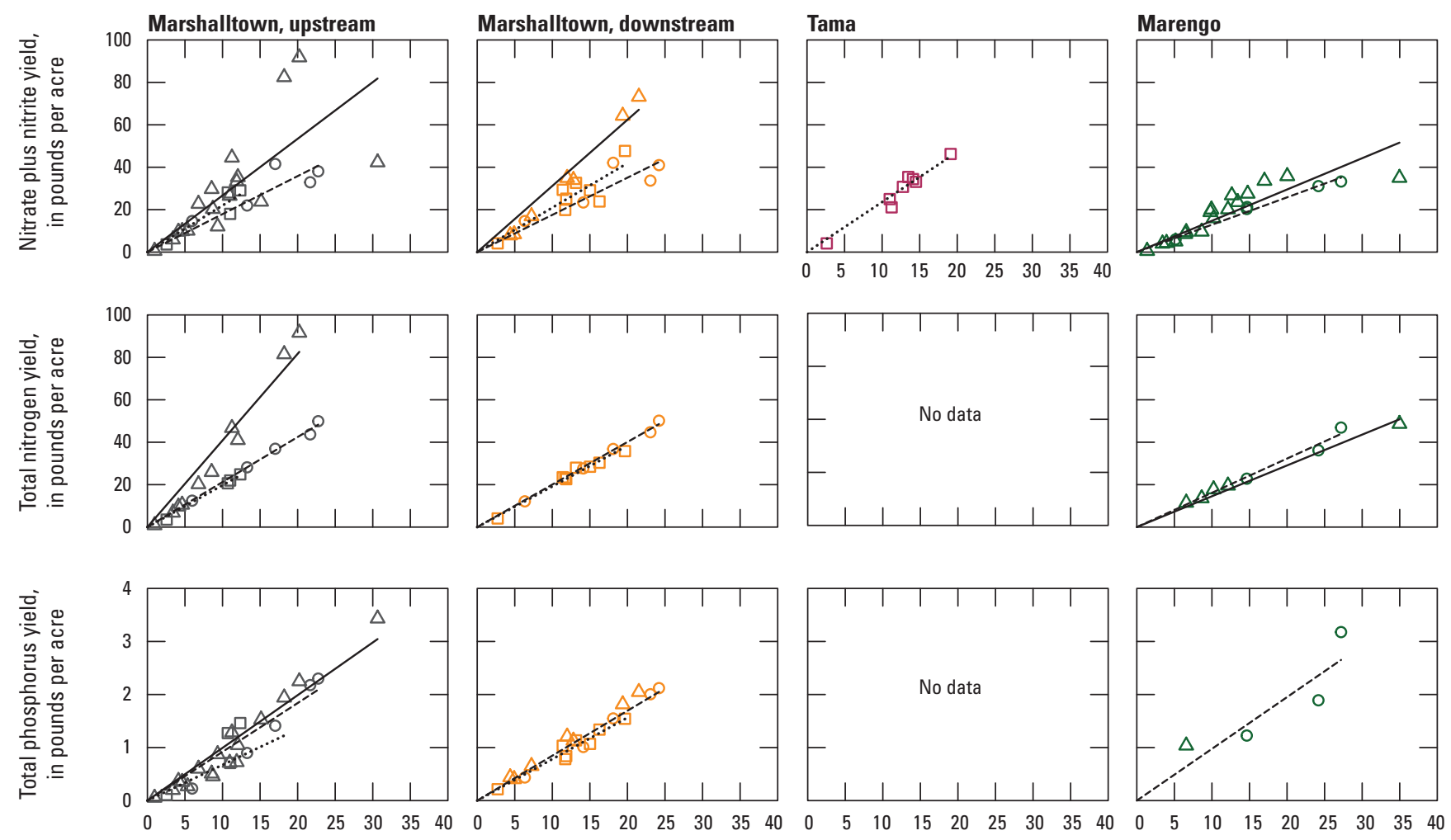

Streamflow runoff, in inches

\section{EXPLANATION}

\begin{tabular}{lc} 
Linear trend line & \multicolumn{1}{c}{ Yield } \\
$-1980-96$ & $\Delta 1980-96$ \\
$----2006-10$ & $\circ 2006-10$ \\
...... 2011-18 & $\square 2011-18$
\end{tabular}

Figure 7. Nutrient yields in relation to annual runoff in the Middle lowa River Basin with linear trend lines for 1980-96, 2006-10, and 2011-18.

\section{Summary}

Annual and seasonal (spring and summer) concentrations, loads, and yields of nitrate plus nitrite (nitrate), total nitrogen, and total phosphorus in the Middle Iowa River Basin were assessed for two historical reference periods, 1980-96 and 2006-10, and for recent years, 2011-18. Historical summaries were used to evaluate potential load reductions. Sample and streamflow data were combined from multiple Federal, State, and Tribal agency sampling programs. Spring and summer loads were compared to annual loads to assess whether seasonal monitoring could describe similar trends in loads. Environmental and human health concerns related to nutrients are also seasonal in nature, with downstream hypoxia and nitrate concentrations greater than drinking water standards being more prevalent in the spring and summer. Runofftransport relations provide an additional tool to evaluate temporal changes in nutrient loads.
Despite increasing streamflow, nitrate, total nitrogen, and total phosphorus concentrations and loads entering the Middle Iowa River Basin have decreased during 2011-18 relative to either 1980-96 or 2006-10 baseline historical reference periods. For example, average annual concentrations in the Iowa River during the 1980-96 baseline period entering the basin upstream from Marshalltown, Iowa, were 6.83, 6.88, and 0.25 milligrams per liter $(\mathrm{mg} / \mathrm{L})$ for nitrate, total nitrogen, and total phosphorus, respectively, compared to 5.05, 5.86, and $0.23 \mathrm{mg} / \mathrm{L}$ for $2011-18$. Average annual yields upstream from Marshalltown, Iowa, decreased from 29.5 pounds per acre (lb/acre) for nitrate, $33.5 \mathrm{lb} /$ acre for total nitrogen, and $0.977 \mathrm{lb} /$ acre for total phosphorus during 1980-96 to 19.7, 17.7 , and $0.887 \mathrm{lb} / \mathrm{acre}$, respectively, during 2011-14. This temporal decrease was less pronounced downstream from Marshalltown, although the upstream to downstream comparison is confounded by changes in sampling regimes. In particular, the longer period (2011-18) lessens the effects of the small loads downstream during the 2012 drought year 
on the temporal decrease. The comparison among periods could not be assessed for the Iowa River near Marengo, Iowa, upstream from Coralville Reservoir, because of insufficient nutrient data.

Overall nitrate concentrations for 1980-2018 in the Iowa River were $7.35 \mathrm{mg} / \mathrm{L}$, compared to $6.24 \mathrm{mg} / \mathrm{L}$ in tributary streams. Total nitrogen concentrations for 1980-2018 in the Iowa River were $8.55 \mathrm{mg} / \mathrm{L}$, compared to $7.62 \mathrm{mg} / \mathrm{L}$ in tributary streams. Total phosphorus concentrations for 1980-2018 in the Iowa River were $0.47 \mathrm{mg} / \mathrm{L}$, compared to $0.22 \mathrm{mg} / \mathrm{L}$ in tributary streams. Maximum concentrations in the Iowa River were $20.4 \mathrm{mg} / \mathrm{L}$ for nitrate, $20.1 \mathrm{mg} / \mathrm{L}$ for total nitrogen, and $4.2 \mathrm{mg} / \mathrm{L}$ for total phosphorus, which were similar to tributary maximum concentrations except for one extreme outlier for total nitrogen of $373 \mathrm{mg} / \mathrm{L}$. Caution is needed when comparing concentration data because sample regimes vary through time and among sites.

Though spring and summer loads accounted for $50-90$ percent of the annual total, reductions in seasonal loads were generally less than reductions in annual total. While annual load reductions were somewhat sensitive to using one or the other historical period, seasonal load comparisons were even more so. One possible reason for the effect of the two different historical periods may be related to trends in streamflow because base-flow and annual trends were significantly upward, whereas high streamflow trends were not significant. Runoff-transport relations provide an additional tool for assessing loads relative to interannual or long-term streamflow trends.

Combining data from multiple sources and loads computed by various techniques provide valuable insights that would otherwise not be possible. However, caution is needed when drawing comparative inferences. Upstream to downstream comparisons, when possible, were based on sampling regimes that were not consistent. This is potentially more problematic with concentration comparisons, which may include sampling with primarily narrow seasonal or hydrologic targets (such as sampling only during open-water seasons or low streamflow).

\section{References Cited}

Helsel, D.R., Hirsch, R.M., Ryberg, K.R., Archfield, S.A., and Gilroy, E.J., 2020, Statistical methods in water resources: U.S. Geological Survey Techniques and Methods, book 4, chap. A3, 458 p., accessed June 29, 2020, at https://doi.org/ $10.3133 / \mathrm{tm} 4 \mathrm{a} 3$.

Hirsch, R.M., 2014, Large biases in regression-based constituent flux estimates - Causes and diagnostic tools: Journal of the American Water Resources Association, v. 50, no. 6, p. 1401-1424, accessed April 2018 at https://doi.org/ 10.1111/jawr. 12195 .
Hirsch, R.M., and De Cicco, L.A., 2015, User guide to exploration and graphic for RivEr Trends (EGRET) and dataRetrieval—R Packages for hydrologic data: U.S. Geological Survey Techniques and Methods, book 4, chap. A10, 93 p., accessed June 25, 2020, at https://doi.org/ 10.3133/tm4A10.

Iowa Department of Agriculture and Land Stewardship, Iowa Department of Natural Resources, and Iowa State University College of Agriculture and Life Sciences, 2017, Iowa Nutrient Reduction Strategy-A science and technology-based framework to assess and reduce nutrients to Iowa waters and the Gulf of Mexico: Ames, Iowa, Iowa State University, 211 p., accessed October 15, 2018, at http://www.nutrientstrategy.iastate.edu/sites/default/files/ documents/2017\%20INRS\%20Complete_Revised $\% 20$ 2017_12_11.pdf.

Iowa Department of Agriculture and Land Stewardship, Iowa Department of Natural Resources, and Iowa State University, 2020, Iowa Nutrient Reduction Strategy-2018-19 Annual Progress Report: Ames, Iowa, Iowa State University, 56 p., accessed January 1, 2021, at https://store.extension.iastate.edu/Product/15915.

Iowa Department of Natural Resources, 2019, AQuIA Water Quality Monitoring database: accessed December 5, 2019, at https://programs.iowadnr.gov/aquia/.

Jones, A.S., Horsburgh, J.S., Mesner, N.O., Ryel, R.J., and Stevens, D.K., 2012, Influence of sampling frequency on estimation of annual total phosphorus and total suspended solids loads: Journal of the American Water Resources Association, v. 48, no. 6, p. 1258-1275, accessed January 3, 2019, at https://doi.org/10.1111/j.1752-1688.2012.00684.x.

Kalkhoff, S.J., 2018, Transport of nitrogen and phosphorus in the Cedar River Basin, Iowa and Minnesota, 2000-15: U.S. Geological Survey Scientific Investigations Report 2018-5090, 44 p., accessed September 18, 2020, at https://doi.org/10.3133/sir20185090.

Kiedrzyńska, E., Kiedrzyński, M., and Zalewski, M., 2008, Flood sediment deposition and phosphorus retention in a lowland river floodplain-Impact on water quality of a reservoir, Sulejow, Poland: Ecohydrology \& Hydrobiology, v. 8, no. 2-4, p. 281-289. [Also available at https://doi.org/ 10.2478/v10104-009-0022-z.]

Lee, C.J., Hirsch, R.M., Schwarz, G.E., Holtschlag, D.J., Preston, S.D., Crawford, C.G., and Vecchia, A.V., 2016, An evaluation of methods for estimating decadal stream loads: Journal of Hydrology (Amsterdam), v. 542, p. 185-203, accessed January 3, 2019, at https://doi.org/10.1016/ j.jhydrol.2016.08.059. 
Lee, C.J., Murphy, J.C., Crawford, C.G., and Deacon, J.R., 2017, Methods for computing water-quality loads at sites in the U.S. Geological Survey National Water Quality Network: U.S. Geological Survey Open-File Report 2017-1120, 20 p., accessed September 18, 2020, at https://doi.org/10.3133/ofr20171120.

Lee, C.J., Norman, J.E., and Reutter, D.C., 2018, Nutrient and pesticide data collected from the USGS National Water Quality Network and previous networks, 1963-2017: U.S. Geological Survey data release, accessed September 18, 2020, at https://doi.org/10.5066/P9TMSQFE.

Littin, G.R., and McVay, J.C., 2009, Water-quality and biological assessment of the Iowa River and tributaries within and contiguous to the Meskwaki Settlement of the Sac and Fox Tribe of the Mississippi in Iowa, 2006-07: U.S. Geological Survey Scientific Investigation Report 2009-5105, 41 p., accessed December 2019 at https://pubs.usgs.gov/sir/ $2009 / 5105$.

Loken, L.C., Crawford, J.T., Dornblaser, M.M., Striegl, R.G., Houser, J.N., Turner, P.A., and Stanley, E.H., 2018, Limited nitrate retention capacity in the Upper Mississippi River: Environmental Research Letters, v. 13, no. 7, p. 074030. [Also available at https://doi.org/10.1088/17489326/aacd51.]

Lorenz, D.L., 2015, smwrBase-An R package for managing hydrologic data, version 1.1.1: U.S. Geological Survey Open-File Report 2015-1202, 7 p., accessed April 2018 at https://doi.org/10.3133/ofr20151202.

Midwestern Regional Climate Center, 2015, Welcome to the cli-MATE database: Midwestern Regional Climate Center web page, accessed December 2019 at https://mrcc.isws.illinois.edu/CLIMATE/.

Mississippi River/Gulf of Mexico Watershed Nutrient Task Force, 2008, Gulf hypoxia action plan 2008 for reducing, mitigating, and controlling hypoxia in the Northern Gulf of Mexico and improving water quality in the Mississippi River Basin: U.S. Environmental Protection Agency web page, accessed September 2017 at https://www.epa.gov/mshtf/gulf-hypoxia-action-plan-2008.

National Water Quality Monitoring Council, 2019, Water-quality portal: accessed December 27, 2019, at https://www.waterqualitydata.us/.

Prior, J.C., 1991, Landforms of Iowa: Iowa City, Iowa, University of Iowa Press, 153 p.

R Core Team, 2019, R-A language and environment for statistical computing: Vienna, Austria, R Foundation for Statistical Computing, accessed April 15, 2020, at https://www.R-project.org/.
Runkel, R.L., Crawford, C.G., and Cohn, T.A., 2004, Load Estimator (LOADEST) - A FORTRAN program for estimating constituent loads in streams and rivers: U.S. Geological Survey Techniques and Methods, book 4, chap. A5, 69 p., accessed September 18, 2020, at https://pubs.usgs.gov/tm/2005/tm4A5/.

Saad, D.A., Argue, D.M., Schwarz, G.E., Anning, D.W., Ator, S.W., Hoos, A.B., Preston, S.D., Robertson, D.M., and Wise, D.R., 2019a, Water-quality and streamflow datasets used for estimating long-term mean daily streamflow and annual loads to be considered for use in regional streamflow, nutrient and sediment SPARROW models, United States, 1999-2014: U.S. Geological Survey data release, accessed September 18, 2020, at https://doi.org/10.5066/ F7DN436B.

Saad, D.A., Schwarz, G.E., Argue, D.M., Anning, D.W., Ator, S.W., Hoos, A.B., Preston, S.D., Robertson, D.M., and Wise, D.R., 2019b, Estimates of long-term mean daily streamflow and annual nutrient and suspended-sediment loads considered for use in regional SPARROW models of the conterminous United States, 2012 base year: U.S. Geological Survey Scientific Investigations Report 2019-5069, 51 p., accessed September 18, 2020, at https://doi.org/10.3133/sir20195069.

Schilling, K.E., Jones, C.S., Wolter, C.F., Liang, X., Zhang, Y.-K., Seeman, A., Isenhart, T., Schnoebelen, D., and Skopec, M., 2017, Variability of nitrate-nitrogen load estimation results will make quantifying load reduction strategies difficult in Iowa: Journal of Soil and Water Conservation, v. 72 , no. 4, p. 317-325, accessed October 15, 2018, at https://doi.org/10.2489/jswc.72.4.317.

Schilling, K.E., Streeter, M.T., Seeman, A., Jones, C.S., and Wolter, C.F., 2020, Total phosphorus export from Iowa agricultural watersheds-Quantifying the scope and scale of a regional condition: Journal of Hydrology (Amsterdam), v. 581, p. 124397, accessed January 31, 2020, at https://doi.org/10.1016/j.jhydrol.2019.124397.

Sprague, L.A., Oelsner, G.P., and Argue, D.M., 2017, Challenges with secondary use of multi-source waterquality data in the United States: Water Research, v. 110, p. 252-261, accessed February 16, 2019, at https://doi.org/ 10.1016/j.watres.2016.12.024.

State of Iowa, 2018, Senate file 512: Iowa Legislature web page, accessed June 2020 at https://www.legis.iowa.gov/ docs/publications/LGE/87/SF512.pdf.

U.S. Census Bureau, 2010, 2010 Census TIGER/Line shapefiles: U.S. Department of Commerce, U.S. Census Bureau web page, accessed September 18, 2020, at https://www.census.gov/geographies/mapping-files/timeseries/geo/tiger-line-file.2010.html. 
U.S. Department of Agriculture, 2011, Rapid watershed assessment, Iowa River, Middle-07080208: accessed December 26, 2019, at https:/www.nrcs.usda.gov/wps/ portal/nrcs/ia/technical/dma/rwa/.

U.S. Environmental Protection Agency, 2008, Gulf Hypoxia Action Plan 2008: Mississippi River/Gulf of Mexico Hypoxia Task Force, 64 p., accessed May 2020 at https://www.epa.gov/sites/production/files/ 2015-03/documents/2008_8_28_msbasin_ghap2008 update082608.pdf.
U.S. Environmental Protection Agency, 2016, STORET Legacy Data Center: accessed December 5, 2019, at https://www3.epa.gov/storet/legacy/gateway.htm.

U.S. Environmental Protection Agency, 2018, Ecoregion maps and GIS Data: accessed December 26, 2019, at https://www.epa.gov/eco-research/ecoregions.

U.S. Geological Survey, 2019, USGS water data for the Nation: U.S. Geological Survey National Water Information System database, accessed December 27, 2019, at https://doi.org/10.5066/F7P55KJN. 


\section{Appendix 1. Tributary Sites}

(Appendix table 1.1 is available for download at https://doi.org/10.3133/sir20205148.)

Site information for summarized tributary samples are presented in table 1.1 in this appendix. Sample result data are available from State and Federal agency sampling programs (U.S. Environmental Protection Agency, 2016; Iowa Department of Natural Resources, 2019; National Water Quality Monitoring Council, 2019; U.S. Geological Survey, 2019).

\section{References Cited}

Iowa Department of Natural Resources, 2019, AQuIA Water Quality Monitoring database: accessed December 5, 2019, at https://programs.iowadnr.gov/aquia/.
National Water Quality Monitoring Council, 2019, Water-quality portal: accessed December 27, 2019, at https://www.waterqualitydata.us/.

U.S. Environmental Protection Agency, 2016, STORET Legacy Data Center: accessed December 5, 2019, at https://www3.epa.gov/storet/legacy/gateway.htm.

U.S. Geological Survey, 2019, USGS water data for the Nation: U.S. Geological Survey National Water Information System database, accessed December 27, 2019, at https://doi.org/10.5066/F7P55KJN. 
For more information about this publication, contact: Director, USGS Central Midwest Water Science Center 400 South Clinton Street, Suite 269

lowa City, IA 52240

319-337-4191

For additional information, visit: https://www.usgs.gov/ centers/cm-water

Publishing support provided by the

Rolla Publishing Service Center 
